\title{
„HARCOWNIK W ŚWIECIE ZAWODOWCÓW”. ROMAN ZIMAND JAKO BADACZ LITERATURY I PISARZ POLITYCZNY
}

Jan Olaszek

Polska Akademia Nauk

[...] została ona napisana przez outsidera, rzecz jasna $\mathrm{w}$ pozytywnym i pochwalnym znaczeniu owego określenia, lub też, ażeby posłużyć się jeszcze innym określeniem autora, napisana została przez „harcownika” jako przeciwieństwo „zawodowca” [...] ta napisana przez outsidera czy też harcownika książka o Boyu-Żeleńskim w pełni wytrzymuje sprawdzenie naukowe i zawodowe. Więcej - w toku owego sprawdzenia okazuje się, że Zimand zgromadził cały szereg obserwacji i interpretacji, jakich w ogóle nie dostrzegali zawodowcy.

Kazimierz Wyka (1961)

\footnotetext{
${ }^{1}$ Biblioteka Instytutu Badań Literackich PAN, Masz. 303, K. Wyka, Recenzja pracy doktorskiej mgra Romana Zimanda Publicystyka literacka Boya-Żeleńskiego, s. 4. Za cenne uwagi do pierwszej wersji artykułu przekazane podczas dyskusji w ramach Interdyscyplinarnego Seminarium Biograficznego w Instytucie Historii Uniwersytetu Łódzkiego dziękuję prowadzącemu je prof. Rafałowi Stobieckiemu oraz dr Annie Brzezińskiej, dr. Andrzejowi Czyżewskiemu, dr Annie Smywińskiej-Pohl i Grzegorzowi Nawrotowi. Za udostępnienie mi kopii posiadanych przez siebie źródeł bądź informacji o nich dziękuję dr. Michałowi Przeperskiemu, dr. Pawłowi Sasance i dr. Tomaszowi Siewierskiemu. Wyrazy wdzięczności winny jestem również obu recenzentom artykułu.
} 
Ludzi łączących pracę naukową $z$ aktywnościa polityczną w czasach PRL było bardzo wielu. Postać Romana Zimanda uważam za interesującą m.in. dlatego, że jego aktywności na dwóch polach - intelektualno-naukowym i politycznym - szczególnie mocno się przenikały. Na refleksję badawcza zasługuje również specyficzna pozycja w życiu naukowym. Zimand z wykształcenia był socjologiem, ale funkcjonował w środowisku literaturoznawców i historyków literatury, refleksją naukową obejmował zróżnicowane tematy i czynił to w sposób odmienny od tego, który był dominujący w otaczających go kręgach.

W niniejszym artykule postaram się znaleźć odpowiedzi na kilka pytań badawczych dotyczących życia i dorobku Zimanda. Na czym polegała specyfika jego dorobku i podejścia do pracy naukowej? Jak funkcjonowały w jego pracy obok siebie refleksja naukowa i pisarstwo polityczne? Jaką rolę odgrywał kontekst polityczny czasów PRL? Jak wyglądały relacje między Zimandem a otaczającym go środowiskiem naukowym? Na ile można go wpisać w koncept ,intelektualisty totalnego"?

Artykuł składa się z kilku części. W pierwszej z nich („Komunista - rewizjonista - opozycjonista”) został krótko przedstawiony życiorys Zimanda. W drugiej („Badacz niecierpliwy”) koncentruję się na pokazaniu jego dorobku i specyfiki podejścia do pracy naukowej. Trzecia część („Intelektualista zaangażowany") dotyczy pisarstwa politycznego Zimanda i przenikania się jego zaangażowania politycznego z pracą naukową. W czwartej (,Zimand - władze - środowisko”) opisuję relacje między trzema aktorami wydarzeń: Zimandem, otaczającym go środowiskiem naukowym i władzami PRL. W piątej opatrzonej śródtytułem „Intelektualista totalny?” próbuję spojrzeć na postać Zimanda z perspektywy tej właśnie kategorii.

\section{/// Komunista - rewizjonista - opozycjonista}

Bohater tego tekstu urodził się w 1926 roku pod Lwowem w bardzo bogatej rodzinie mieszczańskiej o korzeniach żydowskich. W 1940 roku, po aresztowaniu ojca (który wkrótce został rozstrzelany przez Sowietów) wraz z matką został deportowany do Kazachstanu, gdzie skończył technikum felczerskie. Pod koniec 1941 roku zgłosił się jako ochotnik do Armii Andersa, do której trafił też jeden z jego dwóch znacznie starszych braci. Roman Zimand spędził w niej jedynie trzy miesiące. Zetknął się tam z antysemityzmem i brutalnym traktowaniem ze strony innych młodych żołnierzy, po czym pod pretekstem kłopotów zdrowotnych został wydalony ze służby 
(Siwicka 1992: 7; Głowiński 1992: 263; Głowiński, Wołowiec 2018: 67-68)². W 1945 roku przyjechał do Polski jednoznacznie przekonany o potrzebie poparcia budowy ustroju komunistycznego w Polsce. Już w październiku 1945 roku został członkiem Polskiej Partii Robotniczej (nieco ponad trzy lata później automatycznie został członkiem PZPR). W kolejnych latach działał $w$ podstawowych organizacjach partyjnych oraz Związku Walki Młodych, Akademickim Związku Walki Młodych „Życie”, Związku Akademickim Młodzieży Polskiej i Związku Młodzieży Polskiej. Podjął studia medyczne we Wrocławiu, potem przeniósł się na Wydział Humanistyczny, a po przeprowadzeniu się do Warszawy rozpoczął studia socjologiczne na UW, chociaż najbardziej interesowały go kultura i sztuka. Równolegle do studiów pracował kolejno w Zarządzie Wojewódzkim Związku Walki Młodych i „Trybunie Dolnośląskiej” we Wrocławiu, a w Warszawie - w redakcji organu prasowego ZMP, czyli „Po Prostu”, Szkole Partyjnej „Dwulatce” przy KC PZPR (jako korektor), na Uniwersytecie Warszawskim (jako asystent) i w Instytucie Kształcenia Kadr Naukowych przy KC PZPR ${ }^{3}$. Jednocześnie mocno absorbowała go praca dziennikarska, która łączyła się z zainteresowaniami naukowymi. Zimand regularnie publikował artykuły poświęcone przede wszystkim kulturze. Jego teksty propagujące socrealizm ukazywały się m.in. na łamach najważniejszych wówczas pism tj. „Nowa Kultura” i „Trybuna Ludu” (Hellich 2018: 148). Od 1954 roku pracował nawet $\mathrm{w}$ dziale kultury drugiego $z$ wymienionych tytułów ${ }^{4}$.

Zimand należał do formacji młodych fanatycznych zwolenników marksizmu, niezwykle zaangażowanych w jego propagowanie i zwalczanie różnego rodzaju odchyleń. Była to formacja analogiczna do „pryszczatych” w środowisku literackim. Zimand należał do ,janczarów” nowego porządku, choć dokumenty zachowane w Centralnej Kartotece KC PZPR zawierają jego bardzo krytyczne oceny, wskazujące m.in. na trudny charakter

\footnotetext{
${ }^{2}$ Dział Kadr Instytutu Badań Literackich PAN, Akta osobowe Romana Zimanda, sygn. 714, b.p., Życiorys Romana Zimanda, 21 XII 1957; Biblioteka Narodowa, Zakład Rękopisów, akc. 18198/3, Archiwum Michała Głowińskiego, Wspomnienie o Romanie Zimandzie, s. 4-5; Archiwum Akt Nowych, Komitet Centralny PZPR, Centralna Kartoteka, XX/17140, Pismo Zarządu Głównego Związku Akademickiego do Wydziału Personalnego KC PZPR, 16 II 1949, k. 22.

3 Archiwum Uniwersytetu Warszawskiego, k. 1230, Ankieta personalna Romana Zimanda, 23 II 1951, b.p.; tamże, Podanie Romana Zimanda o pracę na UW, 12 V 1950. AAN, Archiwum Szkół Partyjnych, 43/133, Życiorys Romana Zimanda, 3 III 1949, b.p.; tamże, Pismo Kierownika Wydziału Ogólnego do Referatu Personalnego, 1 II 1949, b.p.; tamże, Pismo Kierownik Wydziału Ogólnego do Referatu Personalnego, 26 IX 1950 r. b.p.; tamże, Zaświadczenie Kierownika Archiwum Szkół Partyjnych, 30 IV 1986, b.p.; DK IBL, Akta osobowe Romana Zimanda, sygn. 714, b.p., Życiorys Romana Zimanda, 21 XII 1957, b.p. IKKN był kontynuacja ,dwulatki”; jeszcze w czasie pobytu tam Zimanda zmienił on zresztą nazwę na Instytut Nauk Społecznych przy KC PZPR.

${ }^{4}$ DK IBL, Akta osobowe Romana Zimanda, sygn. 714, b.p., Życiorys Romana Zimanda, 21 XII 1957.
} 
Zimanda i brak umiejętności pracy w grupie 5 . To m.in. te jego cechy miały wpływ na częste zmiany miejsca pracy. W pewnym momencie jego charakter sprowadził na niego poważne kłopoty.

W 1949 roku w związku z antyradzieckimi dowcipami oraz ogólną postawą Centralna Komisja Kontroli Partyjnej PZPR podjęła decyzję o wykluczeniu Zimanda z partii ${ }^{6}$. Ostatecznie do tego nie doszło, gdyż w maju 1950 roku wygłosił samokrytykę podczas zebrania podstawowej organizacji partyjnej na UW. W związku z nią i opinią o poprawie jego postawy zdecydowano o zmianie kary na naganę. Sporządzane w kolejnych latach w IKKN charakterystyki Zimanda również zawierały krytyczne opinie na jego temat, jednak wskazywano w nich również na poprawę jego postawy ${ }^{8}$.

Niełatwy charakter Zimanda łączył się w tamtych latach z niezwykle silnym zaangażowaniem ideowym po stronie komunizmu i uczestniczeniu w poszukiwaniu „różnego rodzaju odchyleń”, co często w praktyce oznaczało „niszczenie ludzi”. Osoby, które zetknęły się z nim w latach stalinowskich, we wspomnieniach wskazywały na jego radykalizm i strach, który wywoływał (Loth 2015: 124; Lipski 1990: 301; Franaszek 2018: 514; Hellich 2018: 148). Sam Zimand opisywał swoją ówczesną postawę następująco: „Na uczelni musieli się mnie bać. Jak biłem, to biłem po oczach. Bo, jeśli już coś robię, to robię porządnie i do końca. Jeśli już jestem komunista, to jestem, a jak ich nie lubię, to naprawdę nie lubię". Wspominał przy tej okazji tekst atakujący socjologa Stanisława Ossowskiego (którego wcześniej był studentem) i podkreślał, że napisał go z własnej woli. Przywoływał również ,rozprawienie się” na zebraniu ZMP z kolega ze studiów Witoldem Jedlickim (za podważenie obowiązującej wykładni na temat jugosłowiańskiego przywódcy komunistycznego Josipa Broza Tity) oraz jeszcze dwie inne sytuacje, w których mocno zaszkodził swoją nadgorliwością konkretnym osobom (Lopieńska, Szymańska 1986: 25). Wspomnieć jeszcze można o atakach prasowych na Czesława Miłosza, którego nazwał „zdrajcą, oraz na krytyka literackiego Ludwika Flaszena, który to

\footnotetext{
${ }^{5}$ AAN KC PZPR, CK, XX/17140, Notatka dot. Romana Zimanda, 19 VII 1954, k. 5; tamże, Pismo Zarządu Głównego Związku Akademickiego do Wydziału Personalnego KC PZPR, 16 II 1949, k. 22; tamże, pismo redaktor naczelnej „Po Prostu” do Wydziału Personalnego KC, 18 II 1949, k. 24-25.

${ }^{6}$ AAN, PZPR, CK XX/17140, Uchwała Centralnej Komisji Kontroli Partyjnej PZPR, 10 XII 1949 r., k 26.

7 Tamże, Uchwała Centralnej Komisji Kontroli Partyjnej PZPR, 4 VIII 1950, k. 48.

8 AAN, ASP, 97/306, Charakterystyka tow. Zimanda Romana, 4 IX 1953 b.p.; tamże, Charakterystyka tow. Zimanda Romana, 10 IX 1953, b.p.; tamże, Charakterystyka tow. Zimanda Romana, 5 VIII 1954, b.p.
} 
zasłużył na miano „świętej dziewicy ideologicznej, której kiedyś pastuchy złożą korne hołdy" (Hellich 2018: 148).

W pierwszej połowie lat 50. Zimand obok tekstów dziennikarskich zaczął publikować swoje pierwsze teksty naukowe. Dotyczyły one kultury $\mathrm{i}$ literatury, gdyż ta dziedzina najbardziej go interesowała. Pisał m.in. o krytyku sztuki z przełomu XIX i XX wieku Antonim Sygietyńskim (Zimand 1953a i 1954; artykuły oparte na pracy magisterskiej) i francuskim pisarzu z XVIII wieku Denisie Diderot (Zimand 1953b). Rozpoczął również pracę nad wspomnianym już doktoratem poświęconym Tadeuszowi Boyowi-Żeleńskiemu'. Jego teksty z tego okresu cechowało typowe dla powstających w stalinizmie prac z dziedziny humanistyki podporządkowanie ideologii marksistowskiej (często w jej zwulgaryzowanej formie). „Startował, jak większość przedstawicieli formacji, która reprezentował, pod znakiem ortodoksyjnego marksizmu stalinowskiego" - pisał o Zimandzie już po jego śmierci Głowiński (1992: 267). Jego późniejsze prace naukowe, łącznie z dokończonym po kilku latach doktoratem, powstawały już w ramach innego paradygmatu.

Tak jak wielu innych ludzi z formacji, która mocno popierała budowę ustroju stalinowskiego, Zimand w 1956 roku zaangażował się w przemiany związane z odwilżą. Trudno jednoznacznie stwierdzić, w którym dokładnie momencie nastapiła przemiana ze stalinisty w zwolennika zmian. Jeszcze trudniej wyrokować, co o niej zadecydowało. Z pewnością istotne znaczenie miało jego ponowne pojawienie się w redakcji „Po Prostu” w maju 1956 roku. Tytuł ten z organu ZMP niewyróżniającego się na tle reszty prasy jesienia 1955 roku zmienił się w pismo rewolucyjnie nastawionych młodych ludzi, którego teksty miały istotne znaczenie dla kształtu odwilży w Polsce i otwierały dyskusje na poszczególne tematy (Władyka 2011: 145). Z pewnością ważnym doświadczeniem w tamtym czasie był wyjazd Zimanda z grupa dziennikarzy do Poznaniu tuż po pacyfikacji robotniczych protestów w czerwcu 1956 roku (Łopieńska, Szymańska 1986: 54; Grzelczak 2016: 201-104; Rafalska 2008: 175). Przez całą jesień Zimand należał do dziennikarzy domagających się daleko idących zmian w systemie - nazywanych często ,wściekłymi” - przede wszystkim jego liberalizacji (Przeperski 2015: 315). Swoje poglądy prezentował na różnego rodzaju wiecach i zebraniach, a także w swojej publicystyce na łamach „Po Prostu”. Krytykował funkcjonowanie cenzury oraz przeciwników zmian określanych

$\overline{9}$ AAN, ASP, 97/306, Plan pracy dysertacyjnej Romana Zimanda pt. Tadeusz Boy-Żeleński, b.d., b.p. 
później jako „natolińczyków”" ${ }^{\text {, }}$, surowo oceniał apologetyczny stosunek do ZSRR, wskazywał na zaprzepaszczenie realizacji socjalistycznych ideałów, w literaturze domagał się krytyki „beriowszczyzny”, potępił interwencję zbrojną ZSRR na Węgrzech (Rafalska 2008: 34-36, 166, 197-198). Ludzie, którzy stykali się z nim jesienią 1956 roku, odnotowali w swoich dziennikach lub wspominali po latach jego dużą aktywność w tym czasie, radykalizm, dobrą orientację w bieżących wydarzeniach, rewolucyjne nastawienie oraz talent wiecowego mówcy (Błażejowska 2019: 362; Urban 2013: 93; Woroszylski 2017: 145-147; Lipski 2010: 73, 146-147; Wróblewski 2008: 79-82; Modzelewski 2016: 306; Kuroń 1990: 109).

Władysławowi Gomułce po dojściu do władzy szybko przestało odpowiadać rewolucyjne nastawienie ludzi takich jak Zimand. Niektóre wystapienia bohatera tego tekstu sprawiły, że I Sekretarz KC PZPR nabrał do niego osobistej niechęci (Lopieńska, Szymańska 1986: 100). Na przykład kilka dni po tym, jak na Krajowym Zjeździe Delegatów Stowarzyszenia Dziennikarzy Polskich (przełom listopada i grudnia 1956 roku) Zimand przekonywał, że kierownictwo partyjne nie może być traktowane jako nieomylne (Władyka 2011: 158), Gomułka na spotkaniu z prezydium tej organizacji szeroko polemizował z jego wypowiedziami, podkreślając, że wyłaniają się z nich wszystkie cechy „ujemnej strony działalności prasy”" Co więcej, kilka miesięcy później, podczas obrad IX Plenum KC PZPR I sekretarz, piętnując „rewizjonistów”, wymienił Romana Zimanda obok Leszka Kołakowskiego i Wiktora Woroszylskiego (Rokicki 2011: 125). Jesienią 1957 roku Zimand najpierw stracił pracę („Po Prostu” zostało zlikwidowane), później został wyrzucony z PZPR, czego powodem miały być „odejście od ideologii socjalistycznej i udział w grupowej walce z linią partii" (Siwicka 1992: 8).

Po Październiku '56 Zimand przez pewien czas wierzył jeszcze w możliwość naprawiania ustroju socjalistycznego. Po latach sam mówił o swoich ówczesnych poglądach: „Byłem zajadłym rewizjonista, czyli tym, który nie zadając sobie pytań dotyczących podstawowych założeń teoretycznych, uznając je za dobre, sądzi, że należy i może uczynić ten ustrój idealnym przez takie czy inne zabiegi" (Łopieńska, Szymańska 1986: 100). Słowa te nieprzypadkowo miały wydźwięk krytyczny, gdyż Zimand poszedł znacznie dalej w swojej ewolucji politycznej, niż przeważnie robili to lu-

\footnotetext{
${ }^{10}$ AAN, Stowarzyszenie Dziennikarzy Polskich, 4/7, Stenogram Plenum Zarządu Głównego Stowarzyszenia Dziennikarzy Polskich, IX 1956, b.p., s. 84-89.

${ }^{11}$ AAN, SDP, 3/107, Wypowiedź I Sekretarza KC PZPR na spotkaniu z członkami Prezydium Stowarzyszenia Dziennikarzy Polskich, 10 XII 1956, b.p., s. 4-8.
} 
dzie zaliczani do formacji „rewizjonistów”. Większość z nich wyznawała poglądy „rewizjonistyczne” do połowy lat 60. lub do Marca '68, a później przechodziła na pozycje wolnościowe i demokratyczne. Zimand $z$,,rewizjonizmem" zerwał wcześniej; odróżniał go też od ludzi o podobnych doświadczeniach rys jednoznacznego antykomunizmu i surowa ocena zaangażowania w czasach stalinowskich. Nie stosował przy tym taryfy ulgowej wobec swojej przeszłości. Jak zauważali później koledzy Zimanda z opozycji, często wracał on do swojej przeszłości i podkreślał, że nic go nie usprawiedliwia (Lipski 1990: 301-302; Niesiołowski 1992: 3).

Od tej pory Zimand byl traktowany przez władze PRL jako przeciwnik. W takiej sytuacji w dziennikarstwie nie miał już właściwie czego szukać i w niewielkim stopniu zmieniało się to do końca istnienia PRL, chociaż w latach 60. publikował artykuły i recenzje na łamach pism „Argumenty” i „Film”. Już wcześniej jego głównym azylem i miejscem realizowania ambicji zawodowych stał się Instytut Badań Literackich PAN, gdzie został zatrudniony na początku 1958 roku. Zajmował się tam przede wszystkim pracą naukową. IBL był miejscem specyficznym, przyciagajacym intelektualistów kojarzonych z opozycja (Błażejowska 2018), do której Zimand coraz bardziej się zbliżał. Przez kilka lat współpracował z Klubem Krzywego Koła, potem pojawiał się w roli obserwatora na procesach studentów represjonowanych po Marcu '68 (Siwicka 2002: 373). Pomarcowy czas w życiu Zimanda wiązał się przede wszystkim z jego osobistym dramatem. Z Polski wyjeżdżała wówczas wraz z matką jego dziesięcioletnia córka (Siwicka 1992: 7). Zimand zostawał w kraju bez rodziny (jeden z jego braci zginął $w$ getcie, drugi przebywał po wojnie na emigracji, na która zdecydowała się też ich matka w 1948 roku). On sam nie wyjechał z kraju ze względu na poczucie odpowiedzialności za budowę ustroju komunistycznego w Polsce (Niesiołowski 1992; Hellich 2018: 152-153; Zieliński 2016: 205). Rozpoczął wówczas pracę nad Materiałem dowodowym - dedykowanym córce esejem poświęconym komunizmowi. Równolegle powstawał osobisty dziennik tego czasu oddający jego dramat rozstania z dzieckiem. Oba teksty ukazały się długo po tym, jak powstały (Zimand 1992: 226296, 297-311). W latach 70. Zimand wyjeżdżał dwukrotnie na Zachód na stypendia - częściowo było to związane z koniecznością opieki nad córką.

$\mathrm{Na}$ początku lat 70. Roman Zimand wziął udział w protestach w obronie braci Jerzego i Ryszarda Kowalczyków skazanych za wysadzenie auli Wyższej Szkoły Pedagogicznej w Opolu, gdzie następnego dnia miała odbyć się uroczystość z okazji święta pracowników Milicji Obywatelskiej i Służby Bezpieczeństwa (Błażejowska 2018: 142-143). W tej samej deka- 
dzie zaczął publikować pod pseudonimami w paryskiej „Kulturze”. Po 1976 roku współpracował m.in. z Polskim Porozumieniem Niepodległościowym, Towarzystwem Kursów Naukowych oraz pismami ukazującymi się poza cenzurą. Od 1976 roku stale podpisywał swoje teksty polityczne pseudonimem „Leopolita”, którym wyrażał swoje przywiązanie do Lwowa. Jesienią 1980 roku Zimand był zaangażowany w działalność Niezależnego Samorządnego Związku Zawodowego Pracowników Nauki, Techniki i Oświaty oraz Towarzystwa Popierania i Krzewienia Nauki (Woroszylski 2017: 396, 405; Siwicka 2002: 374; Loth 2015: 100). Niewiele wówczas publikował, gdyż pozostawał sceptyczny wobec szans ruchu.

W dniu wprowadzenia stanu wojennego zostal internowany ${ }^{12}$. Najpierw przebywał w Warszawie-Białołęce, później w Jaworzu. Towarzyszyli mu tam czołowi opozycyjni intelektualiści (m.in. Stefan Amsterdamski, Władysław Bartoszewski, Bronisław Geremek i Wiktor Woroszylski). Był uczestnikiem życia towarzyskiego, artystycznego i naukowego organizowanego przez samych internowanych; mianowano go „rektorem” tamtejszego uniwersytetu; planował nawet wówczas wydawanie almanachu (Woroszylski 2017: 532, 533, 542, 547). Wraz z kilkoma innymi intelektualistami wyszedł na wolność w kwietniu 1982 roku $^{13}$. W kolejnych miesiącach i latach Zimand angażował się w akcje w obronie osób represjonowanych - m.in. w te organizowane w IBL. Główne formy jego aktywności związane były z istnieniem niezależnego ruchu wydawniczego. Stał się czołowym publicystą drugiego obiegu. Okazjonalnie publikował w różnych czasopismach podziemnych: m.in. „Krytyce”, „Myśli Niezależnej”, „Tygodniku Mazowsze”, „Arce” i „Przeglądzie Wiadomości Agencyjnych”. W różnych okresach stale wspólpracował z „Kierunkami”, „KOS-em” i „Kultura Niezależna”, na łamach których prowadził rubrykę publicystyczną „Moim zdaniem" (Zimand 1983b: 17-18). Był założycielem i współredaktorem własnego pisma podziemnego, czyli „Almanachu Humanistycznego”, który mimo ukazywania się w szczególnych warunkach miał naukowy charakter. W drugim obiegu publikował (częściowo pod nazwiskiem) książki i broszury swojego autorstwa. Zajmował się również pracą organizacyjna związaną ze zdobywaniem pieniędzy, sprzętu drukarskiego i kolportażem publikacji (Siwicka 2002: 374). W latach 1988-1989 sceptycznie odnosił się do negocjacji Okrąłego Stołu, co w dużej mierze różniło go od śro-

\footnotetext{
${ }_{12}$ Archiwum Instytutu Pamięci Narodowej, 0331/492, Wniosek o internowanie Romana Zimanda, b.d., k. 1.

13 Tamże, Szyfrogram dyrektora Biura Śledczego MSW do Komendanta Stołecznego MO w Warszawie, 27 IV 1982, k. 14.
} 
dowiska opozycyjnych intelektualistów, do którego należał (Woroszylski 2019: 162 246). Uważał propozycję rozmów z opozycją za manewr PZPR służący nie tyle wprowadzeniu jakichkolwiek fundamentalnych zmian, ile zyskaniu na czasie (Kaliski 2016: 324). Na skutek szybko postępującej choroby Roman Zimand zmarł w kwietniu 1992 roku.

\section{/// Badacz niecierpliwy}

Dla dalszych moich rozważań najbardziej interesująca jest ta część życia bohatera tego tekstu, która rozpoczęła się w 1958 roku. W IBL Roman Zimand zaistniał w całkowicie nowej roli. Już wcześniej miał do czynienia z nauką, ale od 1958 roku stała się ona zdecydowanie główną formą jego aktywności zawodowej. Jednocześnie wyróżniało go podejmowanie bardzo zróżnicowanej tematyki. Jeśli szukać by w jego dorobku pewnej specjalności, to byłaby to literatura okresu Młodej Polski. Związał się z pracownia w IBL zajmująca się właśnie tym okresem. W ten nurt wpisywała się wspomniana praca doktorska o Boyu, którą Zimand napisał i obronił w 1961 roku w IBL pod kierunkiem Henryka Markiewicza. Zajmował się w niej kilkoma wątkami w twórczości pisarza: moralistyką, wspomnieniami, biografistyką i teorią literatury. Jeszcze w tym samym roku praca została opublikowana w formie książki w nieco zmienionym kształcie i pod innym tytułem: Trzy studia o Boyu (1961). Tego samego okresu dotyczyła druga książka Zimanda, czyli wydana trzy lata później monografia „Dekadentyzm" warsz̧anski (1964), na podstawie której otrzymał stopień naukowy doktora habilitowanego.

Trzecia z monografii pióra Zimanda została poświęcona czasom II wojny światowej i Holokaustu. W 1979 roku paryska Libella opublikowała jego książkę „W nocy od 12 do 5 rano nie spałem”. Driennik Adama Czerniakowa. Próba lektury (1979); jej krajowe wydanie ukazało się dwa lata później (1982). Zimand, analizując dziennik prezesa warszawskiego Judenratu, skoncentrował się na specyficznym rodzaju tekstu, czyli literaturze dokumentu osobistego. Zainteresowanie tym gatunkiem literackim kontynuował, m.in. przygotowując książkę Diarysta Stefan Ż. poświęconą twórczości autobiograficznej Stefana Żeromskiego (1990).

Artykuły naukowe i eseje, które ukazywały się w różnych tomach zbiorowych i czasopismach (niekoniecznie tylko stricte naukowych), znacznie lepiej pokazuja różnorodność zainteresowań pisarza niż zestawienie jego czterech monografii. Zimand w kolejnych dekadach starał się uporządkować owe artykuły i eseje, aby wydać je w zbiorach najczęściej mających 
w tytule słowo „szkice”. Taki właśnie prosty tytuł nosił pierwszy z nich (1965). W związku z zaangażowaniem opozycyjnym Zimanda Szkice drugie bardzo długo nie mogły się ukazać. Od 1975 roku odrzucały je kolejne wydawnictwa; jako że Zimand wciąż publikował różne teksty, przez ten czas zmieniała się planowana zawartość książki (Siwicka 1992: 10). Ostatecznie zbiór pod tym tytułem ujrzał światło dzienne po śmierci bohatera tego tekstu (1992). W międzyczasie szkice Zimanda ukazywały się w wydawnictwach emigracyjnych lub w drugim obiegu wydawniczym (1981a, 1982, 1984, 1989). Zawartość tych książek jest niezwykle różnorodna, a wziąć pod uwagę trzeba również te teksty, które nie zostały w nich zamieszczone.

Zimand nigdy nie przestał się zajmować literaturą okresu Młodej Polski i publikować na ten temat, ale interesował się coraz bardziej polską literaturą współczesna, czego świadectwem są m.in. teksty o twórczości Andrzeja Kijowskiego, Kazimierza Brandysa, Leopolda Tyrmanda i Czesława Miłosza (1965, 1973, 1983, 1984). Dla Zimanda zainteresowanie twórczością tego ostatniego było szczególnie istotne. Po kilku tygodniach od otrzymania przez Czesława Miłosza Nagrody Nobla, w Instytucie Historii PAN odbyła się poświęcona mu konferencja. Według wspomnień Romana Lotha, który współorganizował tę konferencję m.in. z Romanem Zimandem, temu ostatniemu bardzo zależało na wygłoszeniu referatu, któremu nadał osobisty charakter (Loth 2015: 125). Z pewnością wystapienie to miało znaczenie dla bohatera tego tekstu ze względu na artykuł sprzed lat, w którym atakował Miłosza. Tekst o Tyrmandzie z kolei pierwotnie został wygłoszony na konferencji Literatura 乏́le obecna, która odbyła się w listopadzie 1981 roku. Chodziło o cała powojenną literaturę emigracyjna, dzieła pisarzy znajdujących się na indeksie władz i utwory, które ukazały się po 1976 roku w drugim obiegu. Była to właściwie pierwsza inicjatywa badań dotyczących tej tematyki - niezwykle drażliwej z punktu widzenia władz PRL (Ziątek 2016: 374-375). Dodać warto, że w latach 1982-1986 Zimand wraz z dwójką zaprzyjaźnionych z nim pracowników IBL: Januszem Sławińskim i Aliną Brodzką-Wald, prowadził nieoficjalne seminarium poświęcone tej tematyce (Błażejowska 2018: 424).

W mniejszym lub większym stopniu współczesny kontekst polityczny miał również wpływ na badawcze zainteresowania Zimanda zagraniczną literaturą, które zaowocowały tekstami o twórczości George’a Orwella, Włodzimierza Lenina, Alaina Besançona, Ronalda Francisa Hingleya, Borysa Pasternaka, Grigorija Zinowiewa, Fiodora Dostojewskiego i Milana Kundery. Zimand pisał eseje recenzyjne poświęcone autorom tak jak on związanym z demokratyczną opozycją. Należeli do nich: Stefan Kisie-

\section{/ 154 STANRZECZY 1[16]/2019}


lewski, Piotr Wierzbicki i Zbigniew Herbert (Zimand 1965, 1981a, 1982, 1984, 1989, 1992). Zimand wracał również do historii komunizmu w Polsce, poruszając tematy publicystyki „Przeglądu Kulturalnego” oraz sprawy śmierci pierwszego przywódcy PPR Marcelego Nowotki (w posłowiu do edycji dokumentów na ten temat, Zimand 1981b). Zajmował go komunizm (czego najlepszym przykładem może być wspomniany Materiał dowodowy) i współczesna sytuacja w ZSRR. W związku z tym za Michałem Głowińskim należy stwierdzić, że jednym z głównych nurtów zainteresowań Zimanda była sowietologia ${ }^{14}$.

Szczególnie w latach 60. Zimanda interesowały zagadnienia związane z socjologia kultury (zarówno wysokiej, jak i masowej), czego świadectwem były artykuły recenzyjne dotyczące książek Antoniny Kłoskowskiej o kulturze masowej, Andrzeja Zajączkowskiego o inteligencji i Kazimierza Żygulskiego o filmie w środowisku robotniczym. Napisał też esej o Niepokojach amerykańskich Jana Strzeleckiego (Zimand 1965). W tamtym okresie zainteresował się badawczo również literaturą kryminalną, przez wielu uważanych za niegodna uwagi badaczy (Zimand 1963). Zwłaszcza po książce o dziennikach Czerniakowa jednym z głównych nurtów zainteresowań Zimanda był gatunek określony przez niego jako literatura dokumentu osobistego. Zajmował się różnymi utworami tego typu - jeden z bardziej znanych jego esejów to Wojna i spokój o Szkicach piórkiem Andrzeja Bobkowskiego (1984).

Szczególne miejsce wśród zainteresowań Zimanda zajmowała tematyka żydowska, którą zgłębiał od pierwszej połowy lat 70., kiedy pisał książkę o dziennikach Czerniakowa (pierwsza wersja była gotowa na kilka lat przed wydaniem). Warto zadać sobie pytanie, na ile w przypadku Zimanda to zainteresowanie świadczyło o pewnym jego zwrocie ku żydowskim korzeniom? Wskazywałaby na to zamieszczona w książce dedykacja: „Pamięci rodziców - córce w dziedzictwo". Przypomnieć trzeba, że w getcie zginął jeden z jego braci. Zimand od lat 70. brał udział w różnego rodzaju inicjatywach związanych z historią i kulturą Żydów. Na przykład latem 1973 roku wygłosił wykład na jednym ze spotkań organizowanych przez Krzysztofa Śliwińskiego dotyczących tej problematyki w Sekcji Kultury Klubu Inteligencji Katolickiej w Warszawie (Friszke 2011: 64). Zimand uczestniczył $\mathrm{w}$ opozycyjnych obchodach powstania w getcie warszawskim (Kobylarz 2009: 366) i coraz bardziej interesował się Biblią hebrajską ${ }^{15}$. Najważniej-

${ }_{14}$ BN, ZR, akc. 18198/3, Archiwum Michała Głowińskiego, Wspomnienie o Romanie Zimandzie, s. 21.

15 Tamże, s. 16-17. 
szym elementem dorobku Zimanda wpisującym się w ten nurt był jego esej Piotun i popiót (Czy Polacy i Żydzi wrajem sie nienawidzq?) opublikowany pierwotnie w formie odrębnej drugoobiegowej broszury (1987b). Była to próba wyjaśnienia trwałego stanu niezrozumienia w relacjach między oboma narodami, co dobitnie pokazał w krótkiej dedykacji: „Ścianie - groch”. Dekonstruował stereotypy obecne w języku, pokazywał wzajemne winy i uprzedzenia obu stron; wpisywał też polską obojętność wobec Holokaustu w uniwersalny jego zdaniem mechanizm obojętności wobec zbrodni (Grądzka-Rejak, Olaszek: 2020: 156). Jednocześnie pokazywał analogię między doświadczeniami obu narodów (Tomczok 2017: 690). Częściowo związane z tym wątkiem było zainteresowanie Zimanda teorią narodu ( $\mathrm{Zi}$ mand 1992).

W tym niezwykle zróżnicowanym dorobku pisarskim Romana Zimanda znalazło się również miejsce m.in. na analizę jednego z dzieł filozofa Naoma Chomsky'ego (1972), kilka tekstów autobiograficznych (1979, 1983c, 1983d, 1992) oraz niezwykle bogaty dorobek z zakresu publicystyki politycznej, do którego szerzej jeszcze powrócę. Zimand był tłumaczem z angielskiego, francuskiego i rosyjskiego. Jego działalność translatorska obejmowała także prace naukowe oraz eseje literackie. Nie bez znaczenia dla podjęcia się tych aktywności w latach 70 . był tu aspekt finansowy. Z powodu politycznych Zimand nie miał wówczas możliwości publikowania, znajdował się w niełatwej sytuacji finansowej, o czym świadczy fakt, że prowadził niezwykle drobiazgowy i szczegółowy rejestr codziennych wydatków ${ }^{16}$. Podejmował również refleksję nad przekładami literatury (1975).

Autor niniejszego tomu jest człowiekiem dorosłym, lecz wciąż jeszcze nie ustatkowanym. Przynajmniej w zakresie własnych zainteresowań. Znajduje to odbicie i w zestawie pozycji składających się na tę oto książkę. Zdaje się, że wskutek tego Sžkicom brak tak zwanej nici przewodniej, która łączyłaby je w całość. Można by się bronić, przywołując na pomoc modną obecnie integrację humanistyki albo badania z ,pogranicza”. Chwyt ładny, ale w tym wypadku nieuczciwy. Albowiem piszący te słowa pochlebia sobie, że byłby osobnikiem nie ustatkowanym nawet wówczas, gdyby integracja nie była w dobrym tonie. Więc może lepiej przyjąć, że autor jest taki, jaki jest. Tak chyba będzie najrozsądniej. „Orze gęsią” (wedle ładnego określenia Jeża Miłkowskiego) od lat dwudziestu. Kolej-

${ }^{16}$ BN, ZR, akc. 18169/46, Archiwum Aliny Kowalczykowej, Rejestr zarobków i wydatków Romana Zimanda, 1975-1976, rkps (2 zeszyty). 
no jako dziennikarz, trochę krytyk, trochę felietonista, wreszcie socjolog i historyk literatury (1965: 5).

- pisał Zimand we wstępie do Szkicón. Słowa te równie dobrze można odnieść do całości jego dorobku. Bohater tego tekstu zwrócił w nim uwagę nie tylko na zróżnicowanie podejmowanych tematów, lecz także podejść badawczych i ról, w których występował. Jan Zieliński, uczeń i przyjaciel Zimanda, nazwał go „erudyta poprzecznym”. Chodziło nie tylko o oczytanie Zimanda w kilku językach i kilkunastu dziedzinach nauki, ale również, a może przede wszystkim, o „umiejętność krzyżowego korzystania z posiadanej, nie zawsze usystematyzowanej, ale bardzo szerokiej wiedzy w najrozmaitszych dziedzinach" (Zieliński 2016: 205). Pisząc o literaturze, wykorzystywał swój warsztat socjologiczny, a o historii - literaturoznawczy. W jego pracy naukowej pojawiały się odniesienia do kwestii politycznych, zaś jego publicystyka opozycyjna pełna była odniesień do wielu niekiedy odległych od siebie obszarów wiedzy.

W dokumentach, które Zimand złożył, starając się o pracę w IBL w 1957 roku, zwracał uwage na swoje zainteresowania literatura i szeroko rozumianą kulturą; wspominał o swoich pierwszych publikacjach z tego zakresu $^{17}$. Było to istotne m.in. dlatego, że jego socjologiczne wykształcenie różniło go od ogromnej większości pracowników tego instytutu, którzy studiowali wcześniej polonistykę. Skutkiem tego faktu było odmienne podejście do przedmiotu badań, czyli literatury. Nie mniej od analizy tekstu i poszukiwania struktur narracyjnych interesowały go konteksty społeczne i historyczne oraz recepcja badanego dzieła. Sam Zimand często zastrzegał w swoich pracach swoją metodologiczną odrębność od większości badaczy literatury. Na przykład „Dekadentyzm” warszawski sytuował na pograniczu teorii kultury i historii idei. We wstępie do tej książki zwracał uwagę, że $\mathrm{w}$ podjętym temacie najbardziej interesowały go relacje między stanem społeczeństwa a literatura i całą kultura. „Nie chodzi bowiem o to, co «myślała» literatura, lecz - co myśleli ludzie o literaturze, nie tylko o niej i nawet nie przede wszystkim o niej. Dlatego praca niniejsza nie daje się prawdopodobnie zakwalifikować jako historyczno-literacka" (1964: 17).

Zimand zahaczał również o pola badawcze lub metody historiografii. Specyfiką jego książki o Czerniakowie było zbadanie tego dzieła, wcześniej traktowanego przede wszystkim jako źródło historyczne, przy użyciu metod analizy literackiej (Hellich 2018: 151). Podobnie było w wypadku jego

${ }^{17}$ DK IBL PAN, Akta osobowe Romana Zimanda, sygn. 714, b.p., Podanie Romana Zimanda do dyrekcji IBL, 12 XII 1957; tamże, Życiorys Romana Zimanda, 21 XII 1957. 
eseju Rozmowa z... - dokument czy literatura. Przygladał się z perspektywy badacza literatury książkom będącym zapisami rozmów, traktowanym przede wszystkim jako źródła historyczne zawierające wiele pojedynczych informacji, nie zaś jako teksty mające swoją strukturę i poetykę. Zimand analizował dzieła wówczas znane i cieszące się popularnością w środowiskach opozycji w PRL: m.in. Konspire Zbigniewa Gacha, Macieja Lopińskiego i Mariusza Wilka, Hańbe domowa Jacka Trznadla, Mój wiek Aleksandra Wata i Onych Teresy Torańskiej. Analizując pod różnymi względami te książki, ukuł nawet odrębną nazwę dla tego gatunku - „literatura interlokucyjna”. Akcentował tym samym fakt, że jest ona dziełem pytającego i pytanego oraz że powstaje w interakcji między nimi, co ma istotne konsekwencje dla potencjalnych badaczy tego typu tekstów (Zimand 1989: 15). Zimandowi najbliżej było do historyka, gdy pisał posłowie do wspomnianej publikacji źródłowej na temat zabójstwa Marcelego Nowotki. Podkreślał, że zajmuje się on przedmiotem zainteresowania historyków niejako z przypadku, zaś jego tekst nie jest analizą historyczna, prezentować miał w nim jedynie pewną hipotezę (1981b: 38). De facto występował jednak w roli historyka, wykazując się przy tym znajomością literatury i warsztatu historyka, o czym świadczy chociażby świadomość ograniczeń swojego „niehistorycznego” podejścia. Cechy eseju historycznego w dużej mierze wykazywał również Piotun i popiót (Zimand 1987b).

Janusz Sławiński pisał o Zimandzie:

Jego prace, pomysły i projekty miały charakter interdyscyplinarny: do dociekań nad zjawiskami twórczości pisarskiej wprowadzał pytania, których źródła znajdowały się poza standardowa problematyką historycznoliteracką - w jego znawstwie takich dziedzin, jak socjologia, kulturoznawstwo, biografistyka, historia idei, politologia. W pełnych inwencji studiach interpretacyjnych dopracowywał się czegoś w rodzaju metodyki interpretowania faktów pisarskich, obejmującej w równej mierze rzeczywistość tekstów, osobowość pisarza, społeczny i duchowy kontekst jego działań, tradycję i historyczną recepcję dzieła (2000: 262).

Wspominał przy tym, że bohater tego tekstu sam miał określać swoje podejście jako „historyczną socjopsychologię twórczości” (2000: 262). Dodać do tego warto, że Zimand nie tylko przekraczał granice między dziedzinami humanistyki i nauk społecznych w swoich tekstach, ale funkcjonował również na styku różnych środowisk naukowych, utrzymując regu-

\section{/ 158 STANRZECZY 1[16]/2019}


larne kontakty z badaczami najróżniejszych specjalności. W latach 60 . były to kontakty z filozofami i socjologami współtworzącymi tzw. warszawska szkołę historii idei (Zimand 2016: 168-172). We wstępie do „Dekadentyzmu” warszawskiego dziękował m.in. współtworzącemu ją Bronisławowi Baczce (1964: 5); on był też recenzentem tej ksiazżki w czasie przewodu habilitacyjnego Zimanda. W kolejnych latach współtworzył kierowaną przez Zofię Stefanowską w IBL Pracownię Psychosocjologii Literatury (Prussak 2016: 149) ${ }^{18}$. W latach 1976-1981 nieoficjalnie prowadził interdyscyplinarne seminarium noszące popularną nazwę „Porównania” (Loth 2015: 123-124). Na dyskusję poświęcona pierwszej wersji pracy o dziennikach Czerniakowa zaprosił m.in. historyka Władysława Bartoszewskiego i redaktora działu historycznego „Polityki” Mariana Turskiego (Zimand 1982: 5). Warto dodać, że obaj oni występowali jednocześnie w roli „świadków historii”. Zimand nie unikał kontaktów z ludźmi, o których pisał; dotyczyło to również autorów badanych dzieł literackich. Organizował na przykład dyskusję o książce Stanisława Lema (z którym notabene korespondował na temat obecności erotyki w literaturze science fiction $)^{19}$. Zależało mu na uwagach Leopolda Tyrmanda dotyczących poświęconego mu artykułu, w związku z czym nawiązał kontakt również z nim ${ }^{20}$.

Zimand nie pozostawił po sobie żadnego opus magnum. Nie pisał prac, które moglibyśmy nazwać monumentalnymi (Głowiński 1992: 267). Jego na ogół niewielkiej objętości monografie niekiedy przypominały bardziej rozwinięte szkice bądź ich zbiory. Sam pisał o tym wprost we wstępie do „Dekadentyzmu” warszanskiego. Pod wpływem odczytu Kazimierza Wyki Młoda Polska jako problem i model kultury na otwartym posiedzeniu Wydziału Nauk Społecznych Polskiej Akademii Nauk jesienia 1962 roku postanowił podjąć podobny temat w artykule do księgi dedykowanej temu właśnie badaczowi (1964: 5) ${ }^{21}$. „Rzecz jakoś się rozrosła, co po części, być może stało się za sprawą tematu, a po części winą niepowściagliwości autora” przyznawał kokieteryjnie we wstępie (1964: 5). Rozprawy naukowe Zimanda cechował eseistyczny styl pisania. W recenzji jego doktoratu zwracała na to uwage Janina Gorbaczewska, która podkreślała, że rozdziały pracy o Boyu-Żeleńskim nazwała „szkicami” lub „esejami”, nie chcąc w ten sposób podważać ich naukowości, ale podkreślić ich walory. „W tym przypad-

\footnotetext{
${ }^{18}$ Tamże, Życiorys naukowy Romana Zimanda, 6 III 1984, b.p.

19 BN, ZR, akc. 18169/46, Archiwum Aliny Kowalczykowej, List Stanisława Lema do Romana Zimanda, 4 V 1969, b.p.; tamże, list Stanisława Lema do Romana Zimanda, 16 V 1969, b.p.

${ }^{20}$ Tamże, list Leopolda Tyrmanda do Romana Zimanda, 13 X 1983, b.p.

${ }^{21}$ BN, ZR, akc. 18710/3, Archiwum Kazimierza Wyki, List Romana Zimanda do Kazimierza Wyki, 26 III 1962, b.p.
} 
ku oznaczają one stosunek autora do materiału: żywy, świeży, dowodzący osobistego zaangażowania wobec tematyki" - pisała badaczka ${ }^{22}$.

Tym bardziej przymioty te cechowały krótsze teksty Zimanda. Zaprzyjaźnieni z nim badacze zwracali uwagę na ich wartość literacka, skłonność do polemiki, eksponowanie podmiotu autorskiego i atrakcyjność tytułów (Zieliński 2016: 202) ${ }^{23}$. Sam Zimand swoje teksty najchętniej nazywał najczęściej szkicami lub próbami, tak jakby akcentował ich niedoskonałość. Jako eseista byl przywiązany do pisowni angielskiej „essay” lub w wersji spolszczonej „essej”, czego doświadczyło na przykład wydawnictwo „Aneks”, które we wstępie do zbioru jego tekstów zaznaczyło, że zachowało tę drugą formę na prośbę autora (Zimand 1989: 5).

Ulubiona forma tekstów Zimanda miała związek z jego stylem pracy naukowej. Sławiński pisał: „Jego aktywność intelektualna napędzana była niecierpliwością: coś inicjował, stawiał problem, odbywał rekonesans, proponował wstępną interpretację, wszczynał grę badawczą - i następnie oddalał się spiesznie w kierunku innych spraw, które tymczasem zaczęły go zaprzątać” (2000: 263). W podobnym duchu wypowiadał się Głowiński:

Wydaje mi się, że istnieją dwa kontrastowe typy uczonych. Grupę pierwszą tworzą znakomici specjaliści w jednej dziedzinie lub w kilku, ale ściśle określonych i ze sobą powiązanych; w swojej domenie wiedza oni wszystko, wybranej problematyce pozostaja wierni przez długie lata, a niekiedy poświęcaja jej całe zawodowe życie. Typ drugi jest zasadniczo różny; prezentuja go badacze niecierpliwi, których postawa charakteryzowana poprzednio raczej by go nudziła. Szukają oni wciąż nowych tematów i problemów, nie zabiegają o zbudowanie wiedzy pełnej i w miarę ostatecznej, ich niekwestionowaną domeną sa próby. Gdy je przeprowadza, wycofują się z danego pola, pozostawiając jego uprawę specjalistom. Roman Zimand był konsekwentnym, a może nawet skrajnym, przedstawicielem typu drugiego. Był zaprzeczeniem specjalisty w proponowanym znaczeniu tego słowa (1992: 265).

Dodać warto, że Zimand potrafił o badaniu literatury mówić przystępnym językiem. Świadczyć o tym może wywiad udzielony w 1977 roku

${ }^{22}$ BIBL, Masz. 302, Janina Gorbaczewska, Recenzja pracy doktorskiej mgra Romana Zimanda „Publicystyka literacka Boya Żeleńskiego”, s. 1.

${ }^{23}$ BN, ZR, akc. 18198/3, Archiwum Michała Głowińskiego, Wspomnienie o Romanie Zimandzie, s. $19-20,23$. 
dziennikarce Rozgłośni Harcerskiej Joannie Szczęsnej na temat tego, czym jest nauka o literaturze. W zrozumiały dla każdego, a jednocześnie atrakcyjny sposób (m.in. dzięki barwnym porównaniom) Zimand tłumaczył, jak wiedza o literaturze ma się do gustów czytelniczych, do czego jest człowiekowi potrzebna oraz co ją łączy, a co dzieli z naukami ścisłymi ${ }^{24}$.

\section{/// Intelektualista zaangażowany}

Ważny element dorobku intelektualnego Zimanda stanowia teksty publicystyczne jego autorstwa, które ukazywały się w pismach emigracyjnych i drugoobiegowych. Część z nich została zamieszczona w dwóch zbiorach jego tekstów. W 1983 roku drugoobiegowe warszawskie wydawnictwo In Corpore opublikowało zbiór Teksty cymilne przę Leopolite (1983a); w tym samym roku książka ta ukazała się nakładem Instytutu Literackiego w Paryżu (1983b). Obok tekstów już wcześniej opublikowanych pojawiło się tam kilka nowych lub drukowanych po raz pierwszy w całości. Cztery lata później wydawnictwo Grup Politycznych „Wola” opublikowało zbiór Moim zdaniem. Las rzeczy politycznych (1987a). W 1983 roku w tekście Wyznania jawne i ukeryte napisanym specjalnie na potrzeby pierwszej z tych dwóch książek Zimand definiowal swoje zamieszczone w tomie teksty jako „piśmiennictwo polityczne"; siebie samego zaś uważał za pisarza politycznego. Mimo że większość czołowych działaczy opozycyjnych parała się publicystyka, to zdaniem Zimanda osób zasługujących na miano pisarza politycznego było niewiele. Należeli do nich Stefan Kisielewski, „Socjusz” (Zdzisław Najder), „Maciej Poleski” (Czesław Bielecki) oraz kilku niewymienionych z nazwiska ani pseudonimu autorów z jednego z numerów „Głosu”25.

Zimand wspominał też o autorach, których nie cenił. Wydaje się, że głównym kryterium ich oceny było to, czy formułuja, zdaniem Zimanda, realistyczne i ciekawe propozycje polityczne, chociaż podkreślał, że można doceniać pisarza politycznego i jednocześnie zupełnie się z nim nie zgadzać (1983b: 9-10). Z pewnością nie bez znaczenia była też forma wypowiedzi. We wstępie do zbioru Moim żdaniem. Las rzeczy politycznych pisał co prawda, że nie uznaje pisarstwa politycznego za szczególnie wysoki gatunek literatury (wśród wyjątków wymieniał dzieła autorów tej miary co Arystoteles lub Machiavelli), ale za chwilę dodawał: „Sądzę jednak, że i gatunki niskie

\footnotetext{
${ }^{24}$ Ninateka.pl, Rozmowy o nauce. Doktor Roman Zimand wyjaśnia, co to jest i czym się zajmuje nauka o literaturze (zapis audycji prowadzonej przez Joanną Szczęsną w Rozgłośni Harcerskiej, 1977, cz. 1-2).

${ }^{25}$ We wskazanym przez niego numerze ukazały się m.in. teksty programowe „Stanisława Staszka”, czyli Jarosława Kaczyńskiego, oraz „Jerzego Donata”, czyli Ludwika Dorna.
} 
należy uprawiać jako sztukę rzetelnego myślenia i dobrze dobranego słowa" (1987a: 2).

Gdyby chcieć wskazać cechy charakterystyczne drugoobiegowej publicystyki Zimanda, z pewnością można by zaliczyć do nich indywidualizm i krytyczny stosunek wobec ruchu opozycyjnego, który współtworzył. Na przykład w jednym ze swoich tekstów opublikowanych jeszcze w latach 70. poddał krytyce kilka programów politycznych sformułowanych przez działaczy opozycji z różnych środowisk - między innymi związanych z Komitetem Obrony Robotników. W stanie wojennym opowiadał się przeciwko pomysłom zorganizowania strajku generalnego, gdyż uważał go za nierealistyczny. Polemizował z autorami z różnych środowisk. Parokrotnie, kiedy rubryka Moim zdaniem ukazywała się w „KOS-ie”, dystansował się od linii pisma bądź poglądów jego czołowego publicysty, czyli Konstantego Geberta publikującego pod pseudonimem „Dawid Warszawski”; ostatecznie $z$ tego powodu na długo przerwał współpracę z pismem (Olaszek 2018a: 242-243). Miał swoją wyraźną wizję tego, jak pismo powinno wyglądać. W liście skierowanym do redakcji jesienią 1984 roku dokonał jego surowej oceny i proponował zmiany ${ }^{26}$.

Działalność opozycyjna Zimanda, związana z nią rola publicysty politycznego i praca naukowa się przenikały. Kazimierz Wyka w cytowanym fragmencie swojej recenzji dostrzegł cechę pisarstwa Zimanda, o której wspominał później Artur Hellich, badacz literatury autobiograficznej. Pokazywał on, w jaki sposób Zimand, nieskłonny do tekstów autobiograficznych, pisząc o postaciach historycznych bądź literackich, przemycał wyznania bądź refleksje dotyczące samego siebie, w czym zresztą naśladować miał Boya. Zdaniem Hellicha Czerniaków ważny był dla Zimanda nie tylko ze względu na swoją narodowość, lecz także postawę. Badacz przywołał słowa Zimanda na temat niechęci autora analizowanych dzienników do działaczy żydowskich, którzy w obliczu Zagłady wyemigrowali, zostawiając „zwykłych ludzi”. Hellich sądził, że dla Zimanda, który nie chciał emigrować po Marcu z Polski, gdy dla większości Polaków pozostanie w kraju oznaczało życie w państwie komunistycznym, postawa prezesa warszawskiego Judenratu mogła być wzorem (Hellich 2018: 142-146, 152-153). Warto dodać, że w ten wzór częściowo wpisywała się historia jednego z braci Zimanda, który odmówił ukrycia się przed likwidacja getta w Żółkwi - liczył, że do niego nie dojdzie - na skutek czego znalazł się

${ }^{26}$ Archiwum Ośrodka KARTA, IB/187.6.II, Kolekcja czasopisma „KOS”, List „Leopolity” [Romana Zimanda] do redakcji „KOS-a”, 13 IX 1984, k. 4. 
w grupie Żydów zamordowanych w podżółkiewskim lesie (Zimand 1983b: $21-22)^{27}$.

W późniejszym czasie nawiązania do opozycyjnego życiorysu Romana Zimanda pojawiały się wprost w jego pracach historyczno-literackich - opisywał kłopoty, jakie sprawiały mu władze. W notce zamieszczonej na końcu wstępu do książki o Żeromskim Zimand zaznaczał, że skończył ja pisać kilka lat wcześniej, ale została odrzucona przez Państwowy Instytut Wydawniczy (1990: 5). W Piołunie i popiele opisał swoje trudności z otrzymaniem paszportu (1987b: s. 33 ). Do sytuacji politycznej nawiązywał w samych tytułach zbiorów swoich tekstów. Wojna i spokój: s₹kice czpwarte odnosiły się do eseju o Bobkowskim, ale dla wszystkich było czytelne, że również do stanu wojennego. Podobnie działo się w przypadku zbioru Czas normalizacji: sækice cz̧warte opublikowanego w 1989 roku. We wstępie do książki Zimand pisał:

\begin{abstract}
„Normalizacja” to pojęcie należące do nowomowy. Domniemanemu czytelnikowi niniejszego tomu nie trzeba tłumaczyć, co tak pojmowana „normalizacja” oznacza w językach naturalnych, powiedzmy w polskim lub czeskim czy też słowackim. Jak sami komuniści rozumieja pojęcie „normalizacja”, o tym pośrednio świadczy fakt, że dość często po „normalizacji” następuje „liberalizacja", co skądinąd również należy do dykcjonarza nowomowy. Toteż tytuł „Czas normalizacji” oznacza mniej więcej tyle, co lata 1983-1988, bo w tym właśnie czasie powstawały Sžkice czwarte (1989a: 5).
\end{abstract}

Autor konsekwentnie sygnował swoim imieniem i nazwiskiem eseje związane z naukowymi zainteresowaniami (z wyjątkiem tekstu o śmierci Nowotki), podczas gdy publicystykę polityczną uprawiał pod pseudonimami. W 1989 roku na łamach paryskiej „Kultury” ujawnił, że to on jest „Leopolitą, dodając przy tym:

Rozwiązywanie pseudonimu za życia autora jest wyłącznym prawem danego autora. Swój, rozwiązując, (w prasie emigracyjnej pisuję od 1971 r., w tym jako Leopolita od 1976) zaznaczam, że teksty polityczne będę sygnował ustalonym trzynaście lat temu pseudonimem. Oddzielając w ten sposób - na ile to możliwe - pi-

\footnotetext{
${ }^{27}$ www. collections.uscmm.org, Irena Bloch Papers, Irena Bloch.
} 
sarstwo polityczne od socjologii kultury i historii literatury, które są moim zawodem wyuczonym i uprawianym (Zimand 1989b: 80).

Jednocześnie jednak Zimand swoje teksty dotyczące zainteresowań naukowych publikował z konieczności w drugim obiegu bądź na emigracji, co rozmywało wspomniany podział między badaczem i eseistą a opozycjonistą i publicysta politycznym. Dotyczyło to zwłaszcza tworzonego przez niego naukowego podziemnego pisma, czyli „Almanachu Humanistycznego".

Dodać trzeba, że tematy wielu szkiców Zimanda dotyczących literatury często ocierały się mocno o pisarstwo polityczne, czego najbardziej wyrazistym przykładem może być jego tekst na ten publicystycznej książki Piotra Wierzbickiego Myśli staroświeckiego Polaka. Jej autor proponował jako remedium na problemy programowe opozycji odwołanie się do tradycji endecji; zawarł też w książce dość ostrą krytykę tradycji lewicowych. Wywołała ona duże kontrowersje w kręgach opozycyjnych; środowisko wywodzące się z Komitetu Obrony Robotników w dużej mierze słusznie odebrało ja jako atak na siebie (Olaszek 2017: 96-98). To, jak Zimand odniósł się do książki, dobrze pokazuje, w jaki sposób występował on w kilku swoich rolach jednocześnie. Podczas gdy wielu opozycjonistów koncentrowało się na krytyce tez Wierzbickiego, Zimand swoje rozważania zaczął od refleksji nad gatunkiem, do którego, jego zdaniem, należałoby zaliczyć recenzowaną książkę. Podkreślał, że Myśli staroświeckiego Polaka są pamfletem, który uznawał za w pełni uprawniony gatunek, którego tworzenie wiąże się z konsekwencjami dotyczącymi formy książki, ostrości pojawiających się w niej sądów. Podkreślał, że Wierzbicki jest właściwie jedynym reprezentantem gatunku pamfletu politycznego w polskiej opozycji, co powoduje trudności ze zrozumieniem tej formy wypowiedzi. Jednocześnie zwracał uwagę, że gatunek ten z założenia zachęca do polemiki $i$ tak też jest $z$ recenzowaną książka. Sam doceniając dzieło Wierzbickiego i częściowo się z nim zgadzając, polemizował chociażby z tworzeniem demonicznego obrazu opozycyjnych elit (1989a). Tekst ten Zimand mógłby podpisać równie dobrze jako „Leopolita”. Był on wypowiedzia, która zaliczyć należy do pisarstwa politycznego, a jednocześnie odwołanie w nim do wiedzy literaturoznawczej sprawiało, że argumentacja autora była bardziej przekonująca. 


\section{/// Zimand - władze - środowisko}

Zaangażowanie opozycyjne Zimanda skutkowało utrudnianiem mu kariery naukowej przez władze. Nie mógł on na przykład bardzo długo wydać w kraju książki o Czerniakowie jako człowiek będący na celowniku władz (Hellich 2018: 151). Wielokrotnie odmawiano mu paszportu. Chociaż był najbardziej wyróżniającą się postacią w Zespole Historii Literatury Młodej Polski, to nie mógł objąć stanowiska kierownika, chociaż od 1971 do 1975 roku pełnił kierownicze obowiązki (Loth 2015: 122-123, $197)^{28}$. Mimo że dobrze funkcjonował w środowisku iblowskim, to nie do końca mógł czuć się spełniony. Początkowo według Janusza Sławińskiego Zimand pozostawał na uboczu życia naukowego w IBL (2000: 261). Głowiński z kolei wspominał, że jego przyjaciel czuł się pokrzywdzony tym, że w przeciwieństwie do innych pracowników naukowych prawie nie miał doktorantów, nie otrzymywał propozycji pisania recenzji i nie wybierano go do różnych naukowych gremiów. Zdaniem Głowińskiego wynikało to częściowo z niedopasowywania się Zimanda do „rutyn dyscypliny”29. Powodem mogła być też świadomość ewentualnych kłopotów wynikających z jego opozycyjności. Jednocześnie w środowisku funkcjonował bardzo dobrze, zarówno na niwie zawodowej, jak i towarzyskiej.

Jedną z cech środowiska iblowskiego, która ujawniła się zwłaszcza po 13 grudnia 1981 roku, była gotowość do wyrażania solidarności wobec kolegów z pracy represjonowanych za działalność opozycyjną. Szczególne znaczenie miały dwa zbiorowe listy, każdy z nich podpisany przez kilkudziesięciu pracowników tego instytutu (w tym również Zimanda). W kwietniu 1984 roku domagali się oni ponownego zatrudnienia Jana Józefa Lipskiego; a rok później znaczna część środowiska sygnowała protest przeciwko zwolnieniu Bronisława Geremka z Instytutu Historii PAN w związku działalnością opozycyjną (Błażejowska 2018: 437-440). Jeszcze przed pierwszym $z$ tych listów, w listopadzie 1984 roku, w IBL pojawił się nowy dyrektor - Witold Nawrocki, historyk literatury wcześniej związany z Uniwersytetem Śląskim, równolegle kierownik Wydziału Kultury KC PZPR. Miał on spacyfikować nastroje w IBL. W tym celu w instytucie zarządzono przeprowadzenie „przeglądu” kadr. Brano pod lupę dorobek naukowy pracowników i zgodność ich pracy z planami instytutu. Działanie to uderzyło najbardziej w część pracowników najsilniej zaangażowanych

${ }_{28}$ BN, ZR, akc. 18198/3, Archiwum Michała Głowińskiego, Wspomnienie o Romanie Zimandzie, s. 23.

${ }^{29}$ Tamże, s. 31. 
w działalność opozycyjną, zwłaszcza tych, którzy funkcjonowali podobnie jak Zimand, nie zawsze trzymając się form pisarstwa typowych dla pracy naukowej, i publikowali poza oficjalnym krajowym obiegiem; w dużej mierze zresztą z konieczności. W związku z owym „przeglądem kadr” Zimand składał przed powołaną do tego komisją sprawozdanie ze swojej pracy i bibliografię swojego dorobku. Mimo pozytywnej opinii wystawionej mu przez Romana Lotha, czyli bezpośredniego przełożonego ${ }^{30}$, komisja wystąiła o zwolnienie Zimanda. Wśród przyczyn wymieniano brak publikacji naukowych w oficjalnym obiegu w kraju i brak realizacji wcześniej ustalonych planów ${ }^{31}$. Dorobek Zimanda oceniany na podstawie takich kryteriów był niewielki, skoro od kilkunastu lat utrudniano mu publikacje w oficjalnym obiegu. Do tego również książka o dziennikach Czerniakowa wydana wreszcie w Polsce w 1981 roku jako niewpisująca się w plany Pracowni Młodej Polski, w której Zimand był zatrudniony, nie miała większego znaczenia. Wszechstronność zainteresowań, skłonność do zmieniania pól badawczych i zaangażowanie w sprawy publiczne zostały wykorzystane przeciwko autorowi. Paradoksalnie, aby obronić Zimanda, te same cechy były wymieniane przez środowisko jako jego atuty. Co więcej wskazywali na nie w ramach solidarności z autorem również ci, którzy te cechy oceniali krytycznie ${ }^{32}$.

W lipcu 1985 roku Witold Nawrocki wystapił z takim wnioskiem o zwolnienie Zimanda do sekretarza naukowego PAN Zdzisława Kaczmarka ${ }^{33}$. Wówczas podjęto decyzję o zwolnieniu także dwóch innych opozycyjnych pracowników IBL: Jarosława M. Rymkiewicza i Jana Walca. Szybką reakcję środowiska utrudniało fakt, że trójka badaczy została zwolniona w wakacje; nie mogła chociażby zareagować dość szybko Rada Naukowa IBL. Sprawa niemniej stała się na tyle głośna, że na jednej z konferencji odniósł się do niej Jerzy Urban. Zwolnienia tłumaczył nienaukowością dorobku w przypadku Rymkiewicza, brakiem jakiejkolwiek pracy w przypadku Walca. O Zimandzie mówił następująco: „W tym przeglądzie wypłynęła także sprawa Romana Z., o którym jeszcze RWE nie mówi, a który też został zwolniony, czy też ma zostać zwolniony, ponieważ od 1965 roku zawiesił wszelką działalność w kraju, pozostając tylko na etacie IBL”. Przekonywał on, że zwolnienia nie miały nic wspólnego z aktywnością polityczną zainteresowanych.

\footnotetext{
${ }^{30}$ DK IBL, sygn. 714, Opinia Romana Lotha o Romanie Zimandzie 30 IV 1985, b.p.

31 Tamże, Wniosek o zwolnienie Romana Zimanda, b.d., b.p.

32 Relacja Michała Głowińskiego.

33 DK IBL, sygn. 714, Pismo dyrektora IBL do Sekretarza Naukowego PAN, 8 VII 1985, b.p.
}

\section{/ 166 STANRZECZY 1[16]/2019}


Dyrekcja IBL, poinformowała mnie, że są w instytucie osoby, które działaja politycznie sprzecznie z interesem kraju, jeżeli jednak mają osiągnięcia w swej pracy zawodowej, naukowej, to nie stosuje się wobec nich posunięć dyscyplinarnych. Taka jest polityka dyrekcji IBL (1985).

Cała sprawa nie zakończyła się po myśli władz, gdyż Rymkiewicz i Walc wystapili do sądu, który uznał ich zwolnienie za bezpodstawne; pierwszy z nich jednak nie wrócił do pracy, ponieważ dyrektor IBL i rzecznik rządu nie wycofali się ze swoich słów na jego temat, drugi wrócił do pracy, ale został zwolniony dwa lata później pod innym pretekstem (Błażejowska 2018: 479-480; Olaszek 2018b: 340-346). Wówczas zwolnienie Zimanda również nie doszło do skutku, ponieważ jako docent mianowany nie mógł zostać pozbawiony pracy w tym trybie.

W związku z efektami „przeglądu kadr” na posiedzeniu Rady Naukowej IBL na początku listopada 1985 roku doszło do starcia między dyrektorem Nawrockim (który miał również w jej składzie swoich stronników) a grupą opozycyjnie nastawionych członków tego gremium. W odniesieniu do Zimanda Nawrocki powtórzył formułowane wcześniej zarzuty związane z niedostateczną aktywnością, nierealizowaniem planów i wreszcie publikowaniem poza oficjalnym obiegiem. À propos ostatniego zarzutu mówił: „Ten stan schizofrenii badawczej bada na wniosek dyrektora Instytutu Komisja Dyscyplinarna PAN. Wniosek o zwolnienie postawiony był błędnie, jest to docent mianowany, można rozważyć sposób jego istnienia w Instytucie w inny sposób”. Już wcześniej Nawrocki złożył wniosek o zwolnienie Zimanda z powodów dyscyplinarnych. Wówczas w obronie jego dorobku i znaczenia dla IBL i jego środowiska (podobnie jak w przypadku pozostałych ofiar „przeglądu kadr”) wypowiedziało się kilka osób. Najbardziej aktywny był Michał Głowiński, który zwracał uwagę na nowatorskość i znaczenie książki o dziennikach Czerniakowa, która jego zdaniem świadczyła o „klasie intelektualnej autora, niezależnie od tego, czy tekst był formalnie w planie czy nie był". Głowiński zwracał wówczas uwage również na znaczenie nieformalnych seminariów prowadzonych przez Zimanda. Do tego elementu aktywności badacza odniosła się również Maria Janion, powołując się na pracę intelektualną związaną z prowadzonymi przez niego seminariami. Wątek ten podniósł również Roman Loth, który upominał się jednocześnie o uwzględnienie roli Zimanda jako organizatora konferencji, zwracał uwagę na przekazywanie przez dyrekcję IBL władzom nieprawdziwych informacji. Odniósł się też wymownie do 
kłopotów Zimanda z drukiem: ,jest to sytuacja, w której się kogoś nie drukuje, żeby potem móc postawić mu zarzut, że on nie publikował". Publikowania poza oficjalnym obiegiem bronili w łagodniejszy sposób Jerzy Ziomek i Stefan Żółkiewski. „Ja chcę powiedzieć, że nie było dyskusji na tematy historyczne, filozoficzne, a nawet teoretyczno-literackie, na która nie zapraszalibyśmy Romana Zimanda, właśnie dlatego, że jego sposób widzenia był zawsze obiektywny, nawet jeżeli był to sposób zaskakujący" - krótko i dobitnie wypowiedziała się Alina Brodzka-Wald. Nawrocki natomiast trzymał się biurokratycznej retoryki. Podkreślał, że Zimand nie firmował swoim nazwiskiem seminariów, o których była mowa (co spotkało się z ripostą Lotha, że nie pozwoliła mu na to akademia). Dyrektor podkreślał, że do dorobku Zimanda nie chce liczyć jego publikacji z drugiego obiegu. „Wymagałoby to ode mnie wartościujących określeń, których akurat w tym dokumencie nie chciałbym sformułować" - tłumaczył się i podkreślał, że wniosek nie zostanie wycofany ${ }^{34}$. Kilka tygodni po tym zebraniu Rady Naukowej Witold Nawrocki przesłał do Sekretarza Naukowego PAN dokumentację w sprawie Zimanda wraz z komentarzem: „W moim przekonaniu zgromadzony materiał dowodowy wystarcza dla podjęcia działań dyscyplinarnych"35. Żółkiewski i Ziomek, powołując się na jawność postępowania administracyjnego, wystapili o możliwość uczestniczenia w nim w roli obserwatorów (Błażejowska 2018: 493).

W marcu 1986 roku Zimand wraz z grupa związanych z opozycją pracowników IBL nie otrzymał premii decyzja prezydium dyrekcji instytutu (Błażejowska 2018: 478). Formą szykany ze strony władz IBL zastosowaną na początku 1987 roku wobec Zimanda oraz Jacka Trznadla (również związanego z opozycją pracownika IBL) było wstrzymanie wypłacenia im zwyczajowych trzynastych pensji oraz niepoinformowanie ich w żaden sposób o powodach tej decyzji. Podobnie jak poprzednio jako pretekst wykorzystano niewywiązanie się przez nich $\mathrm{w}$ terminie $\mathrm{z}$ podjętych zobowiązań. Sprawa ta była przedmiotem zażartej dyskusji na posiedzeniu Rady Naukowej IBL w lutym 1987 roku. Ostre przemówienie w obronie dwójki kolegów wygłosił wówczas Głowiński, który mówił m.in.:

Ja rozumiem, że pan dyrektor może się nie zgadzać z poglądami Trznadla czy poglądami Zimanda. Pan Dyrektor jest redaktorem

\footnotetext{
34 AIBL 19/63, Stenogram z przebieg posiedzenia Rady Naukowej IBL z 4 XI 1985, b.p., s. 7, 14-26, 34-37.

${ }^{35}$ DK IBL, sygn. 714, Pismo dyrektora IBL Witolda Nawrockiego do Sekretarza Naukowego PAN w sprawie Romana Zimanda, 28 XI 1985, b.p.
} 
naczelnym czasopisma i jest jego ludzkim prawem polemizować z Trznadlem, polemizować z Zimandem, polemizować z kimkolwiek, ale wydaje mi się, że rola publicysty a rola dyrektora naukowego są to dwie różne rzeczy i trzeba to rozdzielać. I tu trzeba powiedzieć, że to co się robi z tymi dwoma kolegami, wydaje się zwykłą nagonką i czymś haniebnym [...] nie wdając się w szczegóły ja wyrażam pełną solidarność z Trznadlem i Zimandem. Poza tym uważam, że sprawa Trznadla i Zimanda jest sprawa precedensowa, ponieważ jest to w pewnym sensie sprawa każdego $z$ nas. Uważam, że nas jako polonistów po prostu obowiązuje obrona kolegów, którzy mają dorobek, którzy się w tej dyscyplinie liczą. Uważam sprawę za precedensową, że jest to sytuacja kafkowska. Trznadel i Zimand są w roli Józefa K. Trznadla i Zimanda się prowokuje do jakichś czynów, żeby potem właściwie ich wyrzucić, a w takiej sytuacji może być każdy z nas. Następnym mogę być ja, a potem może pani prof. [Maria] Janion, potem może nawet pani prof. [Teresa] Kostkiewiczowa. Muszę powiedzieć, że uważam, że tutaj Rada powinna wziąć w obronę naszych kolegów i zdecydowanie się na ten temat wypowiedzieć. Jest to sprawa ludzka i moralna, i zawodowa. Jest to sprawa o podstawowym znaczeniu, że my nie mamy prawa siedzieć cicho, kiedy się organizuje nagonkę na naszych kolegów.

Głowińskiego poparła wówczas m.in. Maria Żmigrodzka. W odpowiedzi Nawrocki podkreślał, że jedynym celem działań podjętych wobec Trznadla i Zimanda jest doprowadzenie do zrealizowania przez nich podjętych zobowiązań ${ }^{36}$.

W ciągu kilku miesięcy Zimand rozliczył się ze swoich zobowiązań, w związku z czym Nawrocki w lipcu 1987 roku wystapił do Komisji Dyscyplinarnej dla Pracowników Naukowo-Badawczych PAN o wycofanie tej sprawy ${ }^{37}$.

To jednak nie był koniec kłopotów w IBL. Nadal nie została rozwiązana sprawa jego nominacji profesorskiej, która ciągnęła się już od kilku lat. Odkąd zrobił habilitację w połowie lat 60 ., przez cały czas pracował na stanowisku docenta. Według Głowińskiego długo w IBL nikt nie występo-

\footnotetext{
36 AIBL, 19/66, Stenogram z posiedzenia Rady Naukowej IBL, 17 II 1987, b.p., s. 17-19, 24-25, 34.

${ }^{37}$ DK IBL, sygn. 714, Pismo dyrektora IBL Witolda Nawrockiego do Bohdana Glińskiego rzecznika dyscyplinarnego przy Komisji Dyscyplinarnej dla Pracowników Naukowo-Badawczych PAN, 28 VII 1987, b.p.
} 
wał $z$ wnioskiem o przyznanie tytułu profesora Zimandowi, zdając sobie sprawę z tego, że ta jest bez szans ${ }^{38}$. W styczniu 1983 roku z wnioskiem o to wystapili Zofia Stefanowska oraz Michał Głowiński. Omawiając dorobek Zimanda, zwrócili oni uwagę m.in. na korzyści dla badań nad literaturą wynikające z jego socjologicznego wykształcenia ${ }^{39}$. W lutym 1984 roku Henryk Markiewicz wycofał się z funkcji recenzenta dorobku Zimanda ${ }^{40}$. Ostatecznie recenzje napisali wspomniani już Jerzy Ziomek i Janusz Sławiński oraz socjolog Jerzy Szacki. Miały one jednoznacznie pozytywny charakter, jednak sprawa nie posuwała się do przodu. Powrócono do niej w 1988 roku. Komisja powołana wówczas przez Radę Naukową IBL zapoznała się z recenzjami i złożyła wniosek do rady o nadanie tytułu Zimandowi.

Sprawa była rozpatrywana na posiedzeniu 28 czerwca 1988 roku. Maria Janion, Roman Loth i Stefan Żółkiewski przytaczali argumenty na korzyść Zimanda. Nawrocki próbował kontrować, podając w watpliwość jego dorobek, na co Janion odpowiadała, wskazując na kłopoty wydawnicze bohatera tego tekstu. Padło dwadzieścia głosów za, osiem na nie, a jedenaście osób się wstrzymało. O tym, że przy 41 głosujących nie udało się uzyskać większości bezwzględnej, wymaganej do pozytywnego rozpatrzenia, zadecydowały dwa głosy nieważne. Niektórzy byli zdania, że należałoby powtórzyć głosowanie, ale do tego nie doszło ${ }^{41}$. Niewchodzący już wówczas w skład rady Michał Głowiński zwracał uwagę, że chociaż niektórzy bronili Zimanda, to w ówczesnej Radzie Naukowej, w której dominowali ludzie lojalni wobec władz PRL, nie głosowali za przyznaniem Zimandowi tytułu profesorskiego również niektórzy instytutowi koledzy. „Było to dla niego szczególnie bolesne. Miał uzasadnioną pretensję do środowiska, że afera ta nie stała się przedmiotem protestu" - pisał Głowiński ${ }^{42}$.

\section{/// „Intelektualista totalny”?}

Pierre Bourdieu pisał o Jeanie-Paulu Sartrze jako twórcy i ucieleśnieniu „intelektualisty totalnego”, czyli „myśliciela-pisarza, powieściopisarza-metafizyka, artysty-filozofa angażującego w toczone w danym momencie walki polityczne cały swój autorytet oraz wszystkie kompetencje, zjedno-

\footnotetext{
${ }_{38}$ BN, ZR, akc. 18198/3, Archiwum Michała Głowińskiego, Wspomnienie o Romanie Zimandzie, s. 29.

${ }^{39}$ DK IBL, sygn. 714, Pismo Zofii Stefanowskiej i Michała Głowińskiego do Komisji Tytułów i Stopni Naukowych przy Radzie Naukowej PAN, 30 I 1983, b.p.

40 Tamże, List Henryka Markiewicza do Stefana Żółkiewskiego 16 II 1984, b.p.

41 AIBL 19/70, Stenogram z posiedzenia Rady Naukowej IBL, 28 VI 1988, b.p., s. 19-26, 36.

42 BN, ZR, akc. 18198/3, Archiwum Michała Głowińskiego, Wspomnienie o Romanie Zimandzie, s. 29.
} 
czone w jego osobie". Słowa te odnosiły się do stworzonego przez Bourdieu pojęcia pola produkcji kulturowej, w ramach którego intelektualiści rywalizują ze sobą o pozycję. Wszechstronne kompetencje są w tym ujęciu atutami owych „totalnych intelektualistów” w dążeniu do uzyskania dominacji w środowisku. Bourdieu pisał o budowaniu autorytetu pozwalającego tworzyć „niesymetryczne relacje” z innymi intelektualistami, „strategii wyróżniania się" polegającej na korzystaniu z kapitału technicznego i symbolicznego zdobytego w wielu dziedzinach i o „koncentracji wszystkich rodzajów kapitału intelektualnego" (Bourdieu 2011: 321, 323).

Zaangażowanie polityczne intelektualistów wpisywało się również w etos inteligencji silnie obecny w polskiej kulturze od XIX wieku. Oprócz przymiotów intelektualnych powinny go cechować poczucie misji do spełnienia i służba wobec całego społeczeństwa. W obu ujęciach ważne jest zaangażowanie w sprawy publiczne, wychodzące poza wąsko rozumianą rolę naukowca-specjalisty. „Intelek tualistą totalnym” nie może być zatem nawet wybitny naukowiec o najszerszych nawet horyzontach zamknięty „w wieży z kości słoniowej” i niezainteresowany resztą świata. „Intelektualista totalny" to ktoś przekraczający granice między specjalizacjami, dziedzinami nauki i rolami społecznymi. To ktoś, czyj głos jest ważny niezależnie od tematu debaty. To ktoś, kto jest „po prostu” autorytetem, a nie autorytetem „od czegoś” (w jednej waskiej dziedzinie).

„Intelektualista totalny” nie musi szybko zdobywać najważniejszych naukowych laurów, nie musi nawet pisać najwybitniejszych dzieł; ważniejsze jest jego bardziej niewymierne znaczenie dla środowiska, prądu intelektualnego lub szkoły badawczej. Przykładem może być socjolog Jan Strzelecki. Długo pisał pracę doktorska, w związku z czym mając już uznana pozycję w środowisku, pozostawał nadal magistrem. Sporo czasu zajęło mu uzyskanie habilitacji; przyczyny tego nie leżały tylko w jego politycznym zaangażowaniu; poza wszystkim przez długi czas nie napisał rozprawy, na podstawie której mógłby ten stopień uzyskać. Strzelecki do stopni i tytułów, kolejnych szczebli akademickiej kariery, wokół których zdobywania w dużej mierze toczy się życie naukowe, nie przywiązywał większej wagi. Ze wspomnień bliskich mu ludzi, z którymi pisząc jego biografię, rozmawiała dziennikarka Magdalena Grochowska, wyłania się obraz człowieka, któremu z trudem przychodziło wywiązywanie się z obowiązków w pracy naukowej i który tym bardziej nie miał serca do spraw administracyjnych; nie bardzo potrafił na przykład starać się o stypendia. Strzelecki nad pisanie szczegółowych rozpraw przedkładał eseistykę (Grochowska 2014: 250-264). Taki też charakter ma jego najważniejsze dzieło, czyli słynne 
Próby swiadectwa (Strzelecki 1971). Niezależnie od cech, które sprawiały, że nie do końca przystawał do świata nauki, jego znaczenie dla polskiego środowiska socjologicznego czy też w ogóle polskiej humanistyki jest niepodważalne; cieszył się dużym uznaniem jako myśliciel, nieodłączny uczestnik życia środowiska, którego idee i głoszone poglądy odgrywały nieporównywalnie większą rolę niż większość „bardziej naukowych” książek.

Czy Roman Zimand był „intelektualistą totalnym”? Trudno udzielić jednoznacznej odpowiedzi na to pytanie. Wydaje się, że nie bez znaczenia dla zasadności używania tego pojęcia jest szczególna pozycja zajmowana przez intelektualistę w polu produkcji kulturowej i polu władzy, w których funkcjonuje, i jego wpływ na ich kształt. O ile w przypadku Sartre’a był on niewatpliwie ogromny, o tyle w odniesieniu do Zimanda nie można tak powiedzieć. Jednocześnie wydaje się, że zajął on jednak istotne miejsce w polskim (a nie światowym) życiu intelektualnym. Ukuta przez niego kategoria „literatury dokumentu osobistego” wpisała się do kanonu dyscypliny ${ }^{43}$. W sformułowany przez Bourdieu koncept ,intelektualisty totalnego" dobrze wpisywał się sposób, w jaki różne sfery jego działalności: działalność opozycyjna, związana z nią rola publicysty politycznego i praca naukowa - się przenikały. To sprawiło, że jego pozycja w środowisku była znacznie bardziej znacząca, niż wynikałoby to jedynie z naukowego dorobku i cenzusu.

Zimand bywał postrzegany w świecie badaczy literatury jako ktoś przychodzący niejako z zewnattrz. Jeśli stanowiło to kłopot, to tylko na początku. Zdaniem Sławińskiego początkowo znajdował się na marginesie głównego nurtu życia naukowego w IBL, by z czasem zacząć odgrywać w nim istotną rolę właśnie ze względu na odmienną naukową tożsamość badawczą:

Odkrywając dla siebie Romana jako postać ważną w środowisku, nie byłem w tym odkryciu odosobniony. Odkrywałem go wraz ze swymi rówieśnikami z najmłodszej wtedy warstwy pokoleniowej IBL-u. Nie ulega wątpliwości, że nasze zainteresowanie, moralne wsparcie i sympatia pomagały mu wyjść z marginesowości i przesuwały go ku centrum sceny życia instytutowego: okazało się, że jest na niej potrzebnym i pożądanym partnerem. Umiał fortunnie wygrać swoją sytuacja jako ktoś, kto do literaturoznawstwa przybył z zewnątrz [...] i nie musi bezwzględnie przestrzegać reguł i zwyczajów tu obowiązujących (2000: 261-262).

${ }^{43}$ Relacja Michała Glowińskiego. 
Słowa te przywodzą na myśl przywoływane wyżej koncepcje Bourdieu dotyczące wykorzystywania przez ,intelektualistę totalnego” zróżnicowanych kompetencji w rywalizacji o pozycję. Zimand był ceniony w środowisku badaczy literatury nie pomimo tego, że się od niego różnił, ale właśnie dlatego, że się różnił. Jego niekonwencjonalne pomysły często inspirowały innych badaczy literatury (Zieliński 2016: 218). Jednocześnie sygnując imieniem i nazwiskiem niektóre opozycyjne listy i petycje, Zimand wykorzystywał swój kapitał znanego badacza literatury do działalności opozycyjnej. Dzięki udziałowi osób cieszących się w różnych sferach autorytetem protesty przeciwko działaniom komunistycznej władzy nabierały większego znaczenia.

$\mathrm{Na}$ koniec trzeba zadać sobie pytanie, czy brak specjalizacji i polityczny kontekst działalności naukowej Romana Zimanda miały tylko korzystny wpływ na wartość jego prac naukowych? Obraz pokazujący jedynie pozytywne aspekty relacji „harcownika” i „zawodowców” (trzymając się określeń Wyki) byłby wyidealizowany. Warto tu przytoczyć dwa fragmenty wspomnień Głowińskiego:

To pewne, że oddziałał nań fakt, iż nie był z wykształcenia filologiem [...]. Oddziałał dwojako. Niekiedy - nie można tego przemilczać - negatywnie, co wyrażało się w pewnych brakach warsztatowych dostrzegalnych w niektórych pracach (mówiłbym tu o swojego rodzaju niepanowaniu nad narzędziami stosowanymi w dyscyplinie). Mial jednak przede wszystkim wpływ pozytywny, chronił przed różnego rodzaju rutynami, sprzyjał świeżości spojrzenia, a także niebanalnemu włączaniu w pole widzenia kontekstów społecznych czy społeczno-historycznych. Ta swoiście ograniczona „nieprofesjonalność” harmonizowała z właściwościami jego pisarstwa. Unikał pedantycznych wywodów, pisał w stylu swobodnego eseju, nie stronił od ujęć literackich. Ów swobodny esej nie był jednak przeciwstawieniem wypowiedzi zdyscyplinowanej, przeciwnie stał się jedną z jej postaci (1992: 266).

Tak ten zaprzyjaźniony z Zimandem literaturoznawca pisał w tekście opublikowanym tuż po śmierci badacza. W niepublikowanych wspomnieniach natomiast, opisujacc ten sam problem, podawał konkretny przykład:

Nie można wszakże zataić, że czasem przejawiał pewną lekkomyślność, podejmując się mówienia o sprawach, na których znał 
się słabo. Tak np. na seminarium socjologicznym prowadzonym przez Aldonę Jawłowską, wygłosił odczyt o postmodernizmie i podobno był to niewypał, okazało się, bowiem, że prelegent wie mniej na omawiany temat niż większość jego słuchaczy. Przypadku tego bym nie uogólniał, w ogromnej większości referaty Romana były dobrze przygotowane $e^{44}$.

W obu wypowiedziach Głowińskiego, tak jak we wspomnieniach innych osób o Zimandzie, zdecydowanie dominuja pozytywne oceny jego badań i roli odgrywanej w środowisku. Równocześnie wydaje się, że właśnie pierwiastek intelektualno-naukowy obecny w jego publicystyce politycznej sprawiał, że „Leopolita” tak mocno wyróżniał się wśród wielu osób publikujących teksty w nieocenzurowanej prasie.

\section{$* * *$}

Warto umiejscowić przypadek Zimanda na szerszym tle. Był on postacia wyróżniającą się, ale jednocześnie należał do pewnego typu ludzi, których cechowały: wszechstronność zainteresowań, nieprzystosowanie do twardych reguł, występowanie w kilku rolach publicznych jednocześnie i polityczne zaangażowanie. Wydaje się, że ludzie tacy jak Zimand, którzy częściowo z powodów politycznych, a częściowo ze względu na swój eseistyczno-publicystyczny styl mogli wykazać w owej biurokracji tylko część aktywności, znajdowali się wówczas w trudnym położeniu. Sprzyjała temu specyficzna sytuacja badaczy literatury, którzy często zajmuja się obok pracy naukowej jednocześnie krytyką literacką, a nierzadko i własną twórczością. Wobec Jarosława Marka Rymkiewicza formułowano zarzut, że część jego dorobku, chociaż jest uprawniona w nauce, to nie wpisuje się w pracę naukowa. W tej sytuacji kluczowe znaczenie miała postawa środowiska naukowego otaczającego represjonowanych badaczy. IBL jako specyficzne miejsce stanowił niezwykle przyjazne otoczenie dla postaci takich jak Zimand. Chociaż z ich obecnością wiązały się różnego rodzaju trudności dla instytutu, to IBL dawał schronienie ludziom, których Marek Zaleski - od lat z związany IBL - nazwal trouble makers ${ }^{45}$. Między innymi im zresztą zawdzięczał swoją szczególną pozycję w polskim życiu intelektualnym.

${ }^{44}$ BN, ZR, akc. 18198/3, Archiwum Michała Głowińskiego, Wspomnienie o Romanie Zimandzie, s. $20-21$.

45 Relacja Marka Zaleskiego. 
W PRL po 1956 roku istniały różnego rodzaju „oazy”, w których znajdowało się miejsce dla takich osób. Rządzący w różnym stopniu w poszczególnych okresach i z różnych powodów tolerowali ich istnienie. Mimo represyjności systemu, zwłaszcza w dużych ośrodkach, w których były silne środowiska akademickie, wychodziły czasopisma społeczno-kulturalne, istniały Kluby Inteligencji Katolickiej, podejmowano różnego rodzaju inicjatywy artystyczne. Ludzie tacy jak Zimand mogli znaleźć tam swoje miejsce.

Bibliografia:

/// Archiwum Akt Nowych: KC PZPR, Archiwum Szkół Partyjnych, Stowarzyszenia Dziennikarzy Polskich.

/// Archiwum Instytutu Badań Literackich: materiały z posiedzeń Rady Naukowej.

/// Archiwum Instytutu Pamięci Narodowej: akta dotyczące internowania Romana Zimanda.

/// Archiwum Ośrodka Karta: kolekcja środowiskowa podziemnego czasopisma „KOS”.

/// Archiwum Uniwersytetu Warszawskiego: akta studenckie i personalne Romana Zimanda.

/// Biblioteka Instytutu Badań Literackich PAN: recenzje pracy doktorskiej Romana Zimanda.

/// Błażejowska J. 2018. Opozycja antyreżimowa w Instytucie Badań Literackich w Polskiej Akademii Nauk w latach 1956-1989, Oficyna Wydawnicza Volumen, Instytut Pamięci Narodowej.

/// Błażejowska J. 2019. Ta historia wciaż trwa. Wspomnienia Jana Olszenskiego, Zysk i S-ka.

/// Bourdieu P. 2001. Reguly sz̨tuki. Geneza i struktura pola literackiego, tłum. A. Zawadzki, Universitas.

/// Dział Kadr Instytutu Badań Literackich: akta personalne Romana Zimanda.

/// Franaszek A. 2018. Herbert. Biografia, t. 1, Znak. 
/// Głowiński M. 1993. Roman Zimand (16 listopada 1926 - 6 kwietnia 1992), „Pamiętnik Literacki”, nr 1, s. 263-269.

/// Głowiński M., Wołowiec G. 2018. Czas nieprzewidżiany. Dluga rozprawa bezpana, wójta i plebana, Wielka Litera.

/// Grądzka-Rejak M., Olaszek J. 2020. Holokaust, pamieć, powielač. Zagłada

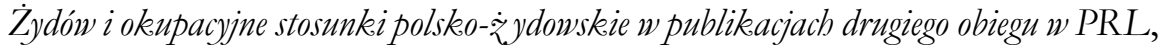
Instytut Studiów Politycznych PAN, Więź, Instytut Pamięci Narodowej.

/// Grochowska M. 2014. Strz̨lecki. Śladem nadziei, Świat Książki.

/// Hellich A. 2018. Gry z autobiografia: przemilczenia, intelektualizacje, parodie, Instytut Badań Literackich PAN.

/// Kaliski B. 2016. Radykaližm czasu przełomu, czyli spór o Okragty Stót w latach 1988-1989, „Polska 1944/45-1989”, nr 14, s. 307-337.

/// Kobylarz R. 2009. Walka o pamiéc. Polityczne aspekty obchodów rocznicy powstania w getcie warszanskim 1944-1989, Instytut Pamięci Narodowej.

/// Kuroń J. 1990, Wiara i wina. Do i od komunizmu, Aneks.

/// Lipski J.J. 1990. Niezrozumialy i pržerażajacy amok. Rozmowa z Janem Józefem Lipskim, [w:] J. Trznadel, Hańba domowa: rozmowy zpisarzami, Wydawnictwo „Test”.

/// Lipski J.J. 2010. Dquienniki 1954-1957, Więź.

/// Loth R. 2015. Zapamiętane. Z lat dawnych Instytutu Badań Literackich PAN, Instytut Badań Literackich PAN.

/// Lopieńska B., Szymańska E. 1986. Stare numery, Aneks.

/// Modzelewski K. 2016. Zajeździmy kobyłe historii. Wyznania poobijanego jeźdíca, Iskry.

/// Muzeum Holokaustu. https://collections.ushmm.org/search/catalog/ irn14150\#? rsc $=186338 \& \mathrm{cv}=0 \& \mathrm{c}=0 \& \mathrm{~m}=0 \& \mathrm{~s}=0 \& \mathrm{xywh}=-1333 \% 2 \mathrm{C}-$ -142\%2C4321\%2C2831; dostęp: 20.05.2020.

/// Niesiołowski S. 1992. Roman, „Życie Warszawy”, nr 91, s. 3.

/// Ninateka.pl. Rozmowy o nauce. Doktor Roman Zimand wyjaśnia, co to jest i czym sie zajmuje nanka o literaturze (zapis audycji prowadzonej przez Joannę Szczęsną w Rozgłośni Harcerskiej, 1977, cz. 1). https://ninateka.pl/audio/ rozglosnia-harcerska-ron-nauka-o-literaturze-cz-1; dostęp: 20.05.2020. 
/// Ninateka.pl. Rozmowy o nauce. Doktor Roman Zimand wyjasnia, co to jest i czym sie zajmuje nauka o literaturze (zapis audycji prowadzonej przez Joannę Szczęsną w Rozgłośni Harcerskiej, 1977, cz. 2). https://ninateka.pl/audio/ rozglosnia-harcerska-ron-nauka-o-literaturze-cz-2; dostęp: 20.05.2020.

/// Olaszek J. 2018a. Podziemne dziennikarstwo. Funkcjonowanie glównych pism informacyjnych podziemnej „Solidarności” w Warszawie w latach 1981-1989, Instytut Pamięci Narodowej.

/// Olaszek J. 2018b. Jan Walc. Biografia opozycjonisty, Trzecia Strona.

/// Prussak M. 2016. Zofia Stefanowska - życie pośród korekt, [w:] IBL w PRL. II. Sylwetki. Wspomnienia, red. E. Kiślak, Instytut Badań Literackich PAN, s. 149-158.

/// Przeperski M. 2015. Odwrót od Października. Pacyfikacja prasy i dziennikarzy w latach 1956-1958, „Pamięć i Sprawiedliwość”, nr 28, s. 311-352.

/// Rafalska-Kuś D. 2008. Międy y marz̧eniami a rzeczymistościa. Tygodnik „Po Prostu" wobec glównych problemów spotecznych i politycznych Polski w latach 19551957, Wydawnictwo Neriton.

/// Rokicki K. 2011. Literaci. Relacje miedzy literatami a władz̧ami PRL w latach 1956-1970, Instytut Pamięci Narodowej.

/// Siwicka D. 1992. Przedmowa, [w:] R. Zimand, Materiat dowodowy. Sælkice drugie, wybór i oprac. D. Siwicka, Instytut Literacki.

/// Siwicka D. 2002. Roman Zimand, [w:] Opozycja w PRL. Stownik biograficzny 1956-89, t. 2, red. J. Skórzyński, P. Sowiński, M. Strasz, Ośrodek Karta, s. $373-374$.

/// Sławiński J. 2000. Teksty i teksty. Prace wybrane, t. 3, red. W. Bolecki, Universitas.

/// Strzelecki J. 1971. Próby swiadectwa, Czytelnik.

/// Tomczok M. 2017. Piołun i popiót... træydzieści lat później, „Zagłada Żydów. Studia i materiały", nr 1, s. 690-703.

/// Urban J. 1985. Konferencja ræ̌ecznika rz̨qdu, „Życie Warszawy”, nr 224.

/// Urban J., Stremecka M. 2013. Jerzy Urban o swoim życiu rozmawia ₹ Marta Stremecka, Czerwone i Czarne. 
/// Władyka W. 2011. Lata 1956-1960, [w:] Crasopisma spoteczno-kulturalne w okresie PRL, red. U. Jakubowska, Fundacja Akademia Humanistyczna, Instytut Badań Literackich PAN, s. 137-168.

/// Woroszylski W. 2017. Džienniki, t. 1.: 1953-1982, Ośrodek Karta.

/// Woroszylski W. 2018, Džienniki, t. 2.: 1982-1988, Ośrodek Karta.

/// Woroszylski W. 2019. Drienniki, t. 3.: 1988-1996, Ośrodek Karta.

/// Wróblewski A.K. 2008. Džienniki zabrane przę bezpieke, Agora.

/// Zakład Rękopisów Biblioteki Narodowej. Archiwum Aliny Kowalczykowej, Archiwum Michała Głowińskiego, Archiwum Kazimierza Wyki.

/// Ziątek Z. 2016. IBL wobec wspótcresności, [w:] IBL w PRL. I. Studia i wspomnienia, red. E. Kiślak, Instytut Badań Literackich, s. 331-387.

/// Zieliński J. 2016. Erudyta poprzeczny. Stare i nowe glossy do portretu Romana Zimanda, [w:] IBL w PRL. II. Sylwetki. Wspomnienia, red. E. Kiślak, Instytut Badań Literackich, s. 201-224.

/// Zimand R. 1953a. Antoni Sygietyński jako krytyk artystyczny, „Materiały do Studiów i Dyskusji z Zakresu Teorii i Historii Sztuki, Krytyki Artystycznej oraz Metodologii Badań nad Sztuką", nr 4, s. 44-128.

/// Zimand R. 1953b. Próba o Diderocie, „Myśl Filozoficzna”, nr 4, s. 312325 .

/// Zimand R. 1954. Kryteria oceny dziet sztuki w krytyce Antoniego Sygietyńskiego, „Materiały i Studia Instytutu Nauk Społecznych przy KC PZPR. Seria historyczna”, t. 1, Książka i Wiedza, s. 214-155.

/// Zimand R. 1961. Træy studia o Boyu, Państwowy Instytut Wydawniczy.

/// Zimand R. 1963. Kilka prac o ,złej” literaturže, „Pamiętnik Literacki”, nr 4, s. 543-556.

/// Zimand R. 1964. „Dekadentyzm” warszawski, Państwowy Instytut Wydawniczy.

/// Zimand R. 1965. Szkice, Państwowy Instytut Wydawniczy.

/// Zimand R. 1973. Rynek, „Teksty”, nr 4, s. 103-110.

/// Zimand R. 1975. Ttumacz-zdrajca i ttumaczenie-zdrada, „Teksty”, nr 6, s. $56-71$. 
/// Zimand R. 1979a. „W nocy od 12 do 5 rano nie spatem”: „Driennik”. Adama Czerniakowa - próba lektury, Libella.

/// Zimand R. 1979b. Lekcje francuskiego: (z. listón nie napisanych), „Teksty”, nr 1, s. 157-165.

/// Zimand R. 1981a. Trzy szkice ₹ lat 1978-1979, Krakowska Oficyna Studentów.

/// Zimand R. [Leopolita] 1981b. Postowie, [w:] Nowotko-Motojec: zpoczatkón PPR: nieznane relacje Wtadystawa Gomutki i Franciszka Jóźwiaka, Głos.

/// Zimand R. 1982a. „W nocy od 12 do 5 rano nie spatem”: dziennik. Adama Cžrniakowa - próba lektury, Państwowy Instytut Wydawniczy.

/// Zimand R. 1982b. Mitos₹, Tyrmand, Zinowiew, Krą.

/// Zimand R. [Leopolita] 1983a. Teksty cywilne przez Leopolite, Instytut Literacki.

/// Zimand R. [Leopolita] 1983b. Teksty cywilne przez Leopolite, In Corpore.

/// Zimand R. 1983c. Gatunek: podróż, „Kultura”, nr 10.

/// Zimand R. 1983d. Gatunek: podróż. (dok.), „Kultura”, nr 11.

/// Zimand R. 1984. Wojna i spokój: škice trzecie, Polonia Book Fund.

/// Zimand R. [Leopolita] 1987a. Moim zdaniem. Las rzeczy politycznych, Grupy Polityczne Wola.

/// Zimand R. 1987b. Piolun i popiót (čy Polacy i Żydzi wrajem się nienawidzq?), Pokolenie.

/// Zimand R. 1989a. Czas normalizacji: szkice czwarte, Aneks.

/// Zimand R. 1989b. Trzy brzydkie choroby polskiej opozycii, „Kultura”, nr 9, s. $75-80$.

/// Zimand R. 1990. Diarysta Stefan Ż., Zakład Narodowy im. Ossolińskich.

/// Zimand R. 1992. Materiat dowodowy. Sæækice drugie, wybór i oprac. D. Siwicka, Instytut Literacki.

/// Zimand R. 2016. Jerzy Giedroyc, Leszek Kołakonski, Roman Zimand, „Przegląd Polityczny", nr 135, s. 168-170. 


\section{/// Abstrakt}

Artykuł dotyczy postaci Romana Zimanda jako badacza kultury i pisarza politycznego. Autor przedstawia życiorys badacza, analizuje jego dorobek i podejście do pracy naukowej, zastanawia się nad jego funkcjonowaniem jako intelektualisty zaangażowanego politycznie, opisuje relacje między trzema aktorami wydarzeń: Zimandem, otaczającym go środowiskiem naukowym i władzami PRL. Wreszcie stawia pytanie o zasadność używania wobec Zimanda kategorii ,intelektualisty totalnego" i zastanawia się nad typowością tego przypadku dla PRL po 1956 roku.

Słowa kluczowe:

Roman Zimand, inteligencja w PRL, opozycja w PRL, Instytut Badań Literackich PAN, intelektualista totalny

\section{/// Abstract}

\section{"A Skirmisher in the World of Professionals": Roman Zimand as a Literary Researcher and Political Writer}

This article is about the journalist, literary researcher, and opposition activist Roman Zimand. The author tries to answer several questions about Zimand's life and achievements. What were his specific achievements and his approach to academic work? What role did the political context of the Polish People's Republic play? What was the relationship between Zimand and the academic community in which he operated? To what extent can he be considered a "total intellectual"? The article begins with a brief biographical outline. Then the author focuses on presenting Zimand's output and the specifics of his approach to academic work. The next part concerns Zimand's political writing and the combination of his political commitment with his scholarship. Then the author discusses the relations between Zimand, the academic community, and the authorities of the Polish People's Republic. In the last part of the article, the author considers the possibility of viewing Zimand as a "total intellectual."

Keywords:

Roman Zimand, opposition in communist Poland, Institute of Literary Research of the Polish Academy of Sciences, total intellectual 
/// Jan Olaszek - doktor, historyk, adiunkt w Instytucie Studiów Politycznych PAN i główny specjalista w Biurze Badań Historycznych IPN. Zajmuje się dziejami PRL, szczególnie historią opozycji demokratycznej. Autor książek Podzৃiemne dziennikarstwo. Funkcjonowanie głównych pism informacyjnych podziemnej „Solidarności” w Warsqawie w latach 1981-1989 (2018), Jan Walc. Biografia opozycjonisty (2018), Przecin PRL. Szkice z dziejón opozycji demokratycznej (2017), Rewolucja powielaczy. Niezależny ruch wydawniçy w Polsce 1976-1989 (2015) i „Nieliczni ekstremiści”. Podziemna Solidarność w propagandzie stanu wojennego (2010). Stypendysta Fundacji na rzecz Nauki Polskiej, Fundacji Kerstenów i Instytutu Badań Europy Wschodniej przy Uniwersytecie w Bremie. Laureat nagród tygodnika „Polityka”: historycznej (2016) i naukowej (2018).

ORCID: https://orcid.org/0000-0002-7700-3256

E-mail: olaszekjan@gmail.com 